Working Paper/Document de travail 2014-15

\title{
The Efficiency of Private E-Money-Like Systems: The U.S. Experience with State Bank Notes
}

by Warren E. Weber 
Bank of Canada Working Paper 2014-15

April 2014

\title{
The Efficiency of Private E-Money-Like Systems: The U.S. Experience with State Bank Notes
}

by

\author{
Warren E. Weber \\ weweber@gmail.com
}

The author joined the Federal Reserve Bank of Minneapolis in 1981 and retired in 2012. His research focuses on monetary and banking theory and history, with particular emphasis on banking in the United States before 1861. This paper was written while the author was a visiting scholar at the Bank of Canada's Currency Department. He is currently a visiting scholar at the Federal Reserve Bank of Atlanta and visiting professor at the University of South Carolina.

Bank of Canada working papers are theoretical or empirical works-in-progress on subjects in economics and finance. The views expressed in this paper are those of the author.

No responsibility for them should be attributed to the Bank of Canada. 


\section{Acknowledgements}

I thank Ben Fung, Miguel Molico, Gerald Stuber, and participants at a seminar at the Bank of Canada for helpful comments on earlier versions of this paper, and Kim Huynh for help with the VARs. 


\begin{abstract}
In the United States prior to 1863 each bank issued its own distinct notes. E-money shares many of the characteristics of these bank notes. This paper describes some lessons relevant to e-money from the U.S. experience with state bank notes. It examines historical evidence on how well the bank notes - a privately-issued currency system with multiple issuers - functioned with respect to ease of transacting, counterfeiting, safety, overissuance and par exchange. It finds that bank notes made transacting easier and were not subject to overissuance. However, counterfeiting of bank notes was widespread, bank notes were not perfectly safe, and notes of different banks did not exchange at par and rates of exchange were volatile. The paper also examines how bank notes were regulated and supervised and how that regulation and supervision affected the functioning of the system. The U.S. experience with state bank notes suggests that a privately-issued emoney system can operate efficiently but only with appropriate government intervention, regulation, and supervision to minimize counterfeiting and to promote safety and par exchange.
\end{abstract}

JEL classification: E41, E42, E58

Bank classification: Bank notes; E-money; Financial services

\title{
Résumé
}

Aux États-Unis, avant 1863, chaque banque émettait ses propres billets. Or, de nos jours, la monnaie électronique présente de nombreux points communs avec ces instruments d'échange. L'auteur décrit quelques enseignements pertinents à l'égard des monnaies électroniques tirés de l'époque où les billets étaient émis par des banques locales aux États-Unis. L'analyse de données historiques permet d'évaluer ce système, dans le cadre duquel les billets étaient émis par de multiples établissements privés, en ce qui a trait à la facilité d'effectuer des transactions, à la contrefaçon, à la sûreté, à la surémission potentielle et à la parité de change. L'étude montre que les billets de banque facilitaient les transactions et n'étaient pas sujets à une émission excessive. En revanche, la contrefaçon était très répandue, les billets ne constituaient pas des instruments parfaitement sûrs, ceux de banques concurrentes ne s'échangeaient pas toujours à leur valeur nominale et les taux de change étaient volatils. L'article traite également de la façon dont ces billets étaient réglementés et supervisés ainsi que de l’incidence du dispositif prudentiel sur le fonctionnement du système. L'expérience américaine au chapitre des billets émis par des banques locales donne à penser qu'un système reposant sur l'émission de monnaies électroniques par des entités privées pourrait fonctionner correctement, à condition d'être régi et supervisé adéquatement par les autorités publiques, et ce, afin d'atténuer le risque de contrefaçon et d'assurer la sûreté ainsi que la parité de change des monnaies en question.

Classification JEL : E41, E42, E58

Classification de la Banque : Billets de banque; Monnaie électronique; Services financiers 


\section{Introduction}

The institutions and technologies that exist in the world today differ from those that existed in the past. Nonetheless, there are many institutions and technologies in the past which bear enough similarities to those that exist today that there is much that can be learned from studying their history. One such case is the notes issued by banks in the United States prior to 1933. These bank notes shared many of the characteristics of the financial instruments that are and would be classified as e-money, which, following Fung, Molico, and Stuber (2014), I define as monetary value represented by a claim on the issuer which is stored on an electronic device, issued on receipt of funds, and accepted as a means of payment by persons or entities other than the issuer. ${ }^{1}$

This paper is the first in a research agenda to describe the lessons relevant to e-money that can be learned from a study of the U.S. experience with bank notes. For this, it is useful to divide the U.S. experience with bank notes into three distinct periods. The first is the period from 1786 to 1863, when virtually every bank issued its own notes. This period is interesting for at least four reasons. One is that there were a large number of banks in existence, so there were a large number of distinct bank notes circulating simultaneously. Another is that bank supervision and regulation were done by the individual states. This led to diversity in the laws and regulations under which banks operated. This period is also interesting because, with only a couple of exceptions, there was a lack of organized note-clearing arrangements and a lack of insurance for bank note holders.

The second is the period from 1864, when the National Banking Act was passed, to 1913, when the Federal Reserve System was established. The banks established under this legislation are called national banks. This period provides an interesting contrast to the previous one because, during it, all banks that issued notes were uniformly chartered, supervised, and regulated by the federal government (the Comptroller of the Currency), rather than by the individual states. Two other contrasts are that during this period there was a centrally organized mechanism for bank note clearing, and bank notes were insured by the federal government.

The third is the period from 1913 until approximately 1933. The Federal Reserve System began issuing its own, fractionally-backed notes after its inception. These notes circulated alongside those of national banks. Thus, this period allows the study of an economy with privately-issued e-money-like media of exchange and a governmentally-issued one. The arguments made at the time for the elimination of national bank notes can also be examined when this period is studied.

The focus of this study is the period from 1786 to 1863 . The objective of the study is to improve our understanding of the problems that existing and future privately-issued e-money systems might face and to determine what can be learned about the roles that regulation and supervision can play in improving the functioning of privately-issued e-moneys as media of exchange. To carry out this objective, I present historical evidence on how well that privately-issued currency system with multiple issuers functioned. I also examine how the

${ }^{1}$ According to my definition, Bitcoin is not considered to be an e-money because it does not have an issuer and thus is not a liability of the issuer. For that reason, Bitcoin and other virtual moneys with similar characteristics are not considered in this study. 
system was regulated and supervised and the role that regulation and supervision played and their effects on the functioning of the system.

In this way, the study sheds light on the question, Can a privately-issued e-money system, with appropriate regulation and supervision, operate efficiently? If the answer is yes, then the finding of this study can be used to make explicit what these regulations should be and how the supervision should be implemented. If the answer is no, then the question becomes, Should government be the sole issuer and completely supplant privately-issued e-moneys by making them illegal, or should it compete with private e-moneys to improve efficiency?

For this study, it would be desirable to determine the efficiency of bank notes as media of exchange. Unfortunately, the data are not available to undertake such a study. Instead, I propose to proxy efficiency by examining the extent to which the state bank note system achieved five desirable characteristics of a money. These characteristics are: ${ }^{2}$

1. ease of transacting - a financial asset will be more desirable as a medium of exchange the easier it is to transport and the less often it either requires a seller to make change or requires the buyer to pay a higher price because of a lack of divisibility;

2. minimal counterfeiting - an extremely low level of counterfeiting or easy detection of counterfeits permits sellers to be relatively certain that they are receiving a valuable asset in exchange for their products or services;

3. high degree of safety - holders of a medium of exchange would like to be relatively certain that the financial instrument they are holding will store value and be acceptable in exchange when they want to use it to make purchases;

4. no overissuance - limitations on the supply of a medium of exchange are essential if it is to be valued or if it is to maintain its value over time; and,

5. par exchange - when there is more than one medium of exchange, it will be desirable if each can be exchanged one-for-one with any other regardless of the identity of the issuer, the location of the issuer, the location of the other issuer, the location in which the exchange is to take place, and the time at which the exchange is to take place. In other words, when there is more than one medium of exchange, it will be desirable if a dollar issued by A exchanges one-for-one with a dollar issued by A or by B always and everywhere. This is relevant because the period I am considering had multiple issuers of bank notes located in numerous towns and cities throughout the country. These notes often circulated outside the location of the issuing bank.

The paper proceeds as follows: Section 2 reviews the monetary arrangements that existed in the United States at the time. Such an understanding is vital to understanding the points

${ }^{2} \mathrm{My}$ list of desirable characteristics for a money is somewhat different from that traditionally found in textbooks. For example, Mishkin $(2009,55)$ lists the desirable characteristics of a money to be easy standardization, wide acceptability, divisibility, ease of carrying, and not deteriorating quickly. These textbook characteristics are incorporated in the first four characteristics in my list. I have simply changed some of the labeling and done some rearrangement to make my list of characteristics a better set of criteria for determining how well bank notes performed as media of exchange. Further, since textbooks do not explicitly consider the case of multiple moneys, I have added par exchange to the list. 
that this study makes. Section 3 argues that bank notes satisfy my definition of e-money given above. Section 4 discusses each of the five desirable characteristics of a money described above. It presents both arguments given at the time, as well as other arguments for why the characteristic is important, relevant, and desirable. It also discusses the regulations on the issuance of bank notes put in place during this period that were intended to make bank notes more desirable media of exchange, and it examines how well the state bank note system performed relative to each of the desirable characteristics. The essential point of this section is that the bank note system did not perform very well. Section 5 discusses the extent to which the shortcomings of the bank note system can be attributed to the regulations under which the system operated. It also considers whether there were regulations that could have been modified or enacted that could have improved the bank note system. It also assesses whether better supervision would have improved the system's performance. Section 6 concludes by returning to the question, Can a privately-issued e-money system, with appropriate regulation and supervision, operate efficiently? It argues that the answer from bank note experience is yes, but only if there is appropriate regulation and supervision. In the Appendix, I discuss the public reaction to the failure on 25 September 1857 of the Bank of Pennsylvania, a large and important bank in the United States during this period. If this bank were in existence today, it might be deemed as being "systemically important" or "too big to fail."

\section{The monetary system in the United States prior to 1863}

Although the United States gained independence from Great Britain in 1783, it did not establish a monetary system until the passage of the Coinage Act in 1792. This Act set up a bimetallic monetary standard with the "dollar" as the unit of account. The Act also established a mint to produce large-denomination gold coins and smaller-denomination silver coins. Minting was "free" in the sense that individuals were able to bring in any amount of bullion to the mint and receive the same weight of coins of the same metal. Further, they were not charged for that coinage; that is, the mint did not charge seigniorage. However, there was no provision for the mint or any other authority to swap one denomination of coin for another.

There was only one bank in the United States prior to its gaining independence. It was the Bank of North America located in Philadelphia. It was chartered by the state of Pennsylvania. It came into existence on 26 March 1782. As Figure 1 shows, the number of banks grew rapidly after independence. By 1800, there were 24 banks in existence; by 1830, 328 were in existence; and by $1860,1,547$ were in existence.

There were two ways in which an individual or group of individuals could establish a bank. The most common was to obtain a charter from the state in which the bank would be located. A charter was a specific piece of legislation allowing the establishment of a bank. Although the specifics varied from charter to charter, in general a bank's charter gave the name of the bank, its location (in most states, banks were restricted to one bricks-andmortar location), the minimum capital requirement, the maximum amount of notes it could issue, the liability of the shareholders, restrictions on the types of assets the bank could hold (in general, they were not permitted to own real estate other than for their building), and restrictions on the types of activities they could pursue. More than $60 \%$ of the banks that 


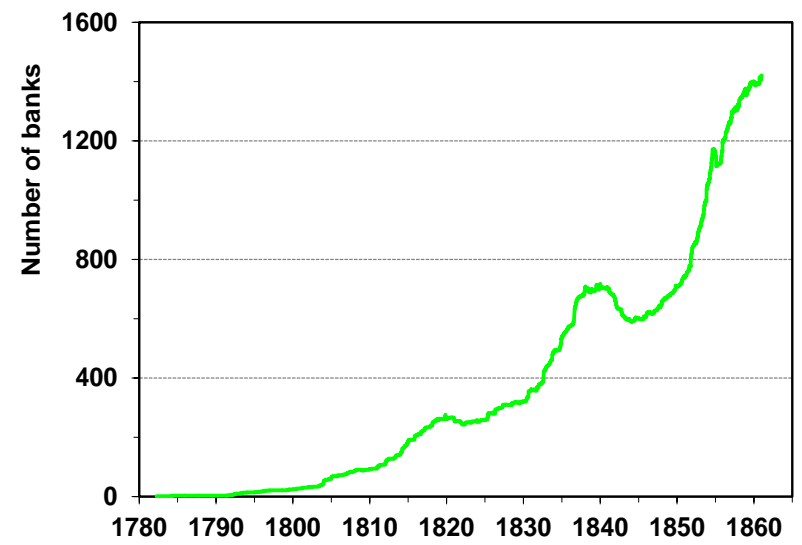

Figure 1: Number of state banks in the United States, 1782-1860

were ever in existence during this period were established under a state charter.

The second way in which an individual or group could establish a bank was under a socalled "free banking law," the first of which was passed by the state of Georgia in 1837. These laws were referred to as free banking laws because they permitted free entry into banking. That is, these laws permitted an individual or group of individuals to set up a bank without going to the state legislature to obtain a charter. However, in no sense was free banking laissez-faire banking. Individuals could establish a free bank only if they followed a specific set of requirements. The most noteworthy of these requirements was that a bank established under these laws had to deposit with the state banking authority, as backing for their note issue, state bonds with a value that was $100 \%$ (or greater in most cases) of the amount of its note issue. This explicit collateral requirement for note issuance was in contrast to state chartered banks that, in essence, could use any asset in their portfolio to "back" their notes. ${ }^{3}$

That bank notes were an important medium of exchange during the period is shown in Table 1, which shows holdings of specie and bank notes by individuals for selected years. ${ }^{4}$ Until 1850, bank notes constituted more than two-thirds of the total supply of media of exchange (specie + bank notes). The fraction fell to one-half or slightly less after 1850 . This fall was likely due to uncertainty about the health of banks given the bank panics that occurred in 1854 and 1857, and to the coming of the Civil War that began in 1861. However, even in 1860 bank notes were a significant medium of exchange. ${ }^{5}$

\footnotetext{
${ }^{3}$ There were also two federally chartered banks that were in existence at different times during this period. The first was in existence from 1791 until 1811 and the second from 1816 until 1836. Both had the name Bank of the United States and had several branches, each of which issued its own notes, which were identifiable by branch and redeemable in specie only at that branch. I have not included them in this study, however, because of the short periods of time in which they were in existence.

${ }^{4}$ The source of the data is Rutner (1974). The estimates are for either October or November from his Table 29, except for 1860, where the estimate is for July.

${ }^{5}$ In contrast to today, deposits were not a large or important medium of exchange during this period.
} 


\begin{tabular}{rrrc} 
& Bank notes & Specie & \multicolumn{2}{c}{ Bank notes as } \\
Year & \multicolumn{2}{c}{ (in thousands) } & media of exchange $(\%)$ \\
1835 & 94,902 & 21,900 & 81.3 \\
1840 & 82,860 & 38,600 & 68.2 \\
1845 & 91,462 & 38,400 & 70.4 \\
1850 & 128,330 & 58,800 & 68.6 \\
1855 & 163,565 & 154,600 & 51.4 \\
1860 & 183,225 & 205,300 & 47.2
\end{tabular}

Table 1: Estimates of holdings of bank notes and specie by individuals, 1835-1860, selected years

\section{Similarities between state bank notes and today's e-moneys}

In this section, I discuss the similarities between state bank notes and e-money that make studying the experience with bank notes useful for learning about how a privatelyissued currency system could work.

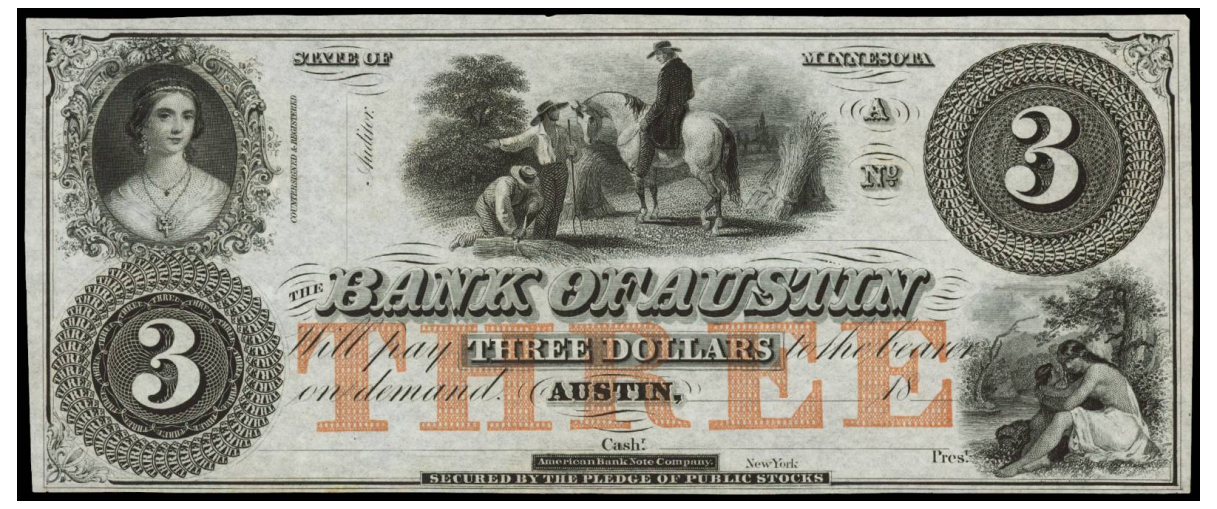

Figure 2: A representative state bank note

A representative state bank note is shown in Figure 2. This note displays three of the characteristics of bank notes that satisfy my definition of e-money: the bank notes were denominated in U.S. dollars, distinguishable by issuer, and were the liability of the issuer. Although not shown on the note, bank notes were are also widely accepted as media of exchange. To state the point slightly differently, bank notes satisfy my definition of e-money if "stored on an electronic device" is replaced by "printed on a piece of paper."

The only question about whether state bank notes satisfy my definition is that my definition implies that e-money is prepaid and thus is not issued on credit. This was most certainly not the case with regard to the issuance of bank notes. In general, they were not issued in exchange for specie. Instead, they were issued when the issuing bank discounted promissory notes or bills presented by the customer. In other words, they were issued as a part of normal bank lending operations, in much the same way as deposits are issued when customers obtain loans from modern-day banks. However, I see no reason why this difference 
should matter for drawing any lessons from how bank notes functioned as to how e-moneys might function. ${ }^{6}$

\section{Desirable characteristics of moneys}

In the introduction, I described five desirable characteristics of privately-issued media of exchange. In this section, I present historical and modern-day arguments for why each of these characteristics is deemed to be desirable in a medium of exchange. Also, for each characteristic, I discuss the regulations on the issuance of state bank notes put in place prior to 1863 that were intended to make bank notes more desirable as media of exchange in the United States. Finally, I examine how well the state bank note system performed relative to each of the desirable characteristics.

\subsection{Ease of transacting}

That a medium of exchange should permit easy transacting seems intuitively obvious. Further, as noted in the introduction, it underlies almost all of the desirable characteristics of a medium of exchange conventionally mentioned in textbooks.

During our period of interest, contemporaries recognized that ease of transacting was an important characteristic of a medium of exchange. Given that the media of exchange at the time were specie and bank notes, ease of transacting was discussed in the context of the advantages of transacting with bank notes rather than coin. These advantages were ease of carrying and transporting, and greater safety against theft. This is shown by the following excerpts from Hildreth $(1840,140)$ :

\footnotetext{
${ }^{6}$ State bank notes also had some other characteristics. They were bearer financial instruments that were not refillable and were issued in a limited number of denominations. They were also redeemable on demand in specie, but only fractionally backed. There is nothing in these characteristics of bank notes that is inconsistent with my definition of e-money. In fact, they represent some characteristics that e-moneys might have today. As one example, a privately-issued e-money could include redemption in legal money on demand as a characteristic, because it might have the effect of enhancing demand and it would permit private monitoring of the issuer. Another example is that a privately-issued e-money could be a bearer instrument in the sense that no type of identification, such as a personal identification number, would be required before they could be used in a transaction. It seems likely that many privately-issued e-moneys would not include identification requirements because the lack of such requirements would enable holders to transact conveniently and completely anonymously. However, a counter argument is that there is a growing tendency among regulators to require e-money issuers to "know their customers." As a third example, my definition of e-money says nothing about how the e-money would be backed, presumably leaving that up to the institution regulating the issuer. Obviously, privately-issued e-moneys could be fractionally backed by legal money, so that they could be similar to bank notes in this regard. However, there is a trade-off here. Permitting privately-issued e-moneys to be fractionally backed increases their profitability and reduces or eliminates the need for the issuer to charge transaction fees. As an example, Safaricom, the issuer of MPESA, is required to hold $100 \%$ reserves against the amount of M-PESA issued. It charges transaction fees. However, as a counter-example, the three note-issuing banks in Hong Kong - HSBC, Standard Chartered Bank, and Bank of China - do not charge fees for withdrawing notes, and notes issued have to be 100 percent backed by their holdings of US\$-denominated Certificates of Indebtedness issued by the HKMA. These banks do not charge transaction fees becasue the ability to issue notes enhances their reputation; that is, they are seen to be safe and too important to fail. This allows them to raise deposits at a lower rate and do more business.
} 
... for a note is much more convenient to send or carry than coin of the same value... The facility of sending bank notes from one place to another by mail, or otherwise, enclosed in letters or small packages, is also a very great convenience, not to be enjoyed in the case of metallic money.

Ease of transacting was also recognized as important for another reason - it was difficult to conduct transactions when the making of change was involved. At one point during the period, several banks issued notes in denominations of $\$ 11, \$ 12, \$ 13$, and $\$ 14$ to facilitate the making of change. It was difficult to make change because almost all banks were restricted as to the denominations of the notes that they could issue. The following was printed in the New-York Commercial Advertiser on 23 May 1837:

The Phenix Bank [of New York City] - The law prohibits the banks from issuing any bills of denominations between five and ten. Still, great inconveniences exist in the payment of fractions between ten and fifteen dollars. To obviate this difficulty, the Phenix Bank is about to issue bills of the denominations of eleven, twelve, thirteen, and fourteen dollars.

At least six other New York banks issued bills of these denominations.

In one respect, the bank note system did not make transacting easy. Divisibility was limited. Banks did not typically issue notes in all possible denominations and there were restrictions on the minimum denomination of notes that could be issued. This led to problems mentioned above.

However, overall, bank notes made transacting easy considering the time period. Transactions with specie faced the same divisibility issues: specie came in a limited number of denominations, and the U.S. Mint was not willing to exchange one denomination into an equal monetary value of other denominations. Additionally, paper is much lighter than metal, so it was far more convenient and less expensive to carry and transport with bank notes than specie.

\subsection{Minimal counterfeiting}

An extremely low level of counterfeiting or easy detection of counterfeits is a desirable characteristic of a medium of exchange. The primary reason is that it gives holders a high degree of confidence that the asset is storing value, in the sense that it will be considered valuable when presented as payment in the future. Another way of looking at the benefit of minimal counterfeiting is that if the probability is low that the financial asset being offered for a purchase is a counterfeit, sellers have a high degree of certainty that they are receiving a valuable asset in exchange for their products or services.

Whether minimal counterfeiting was recognized as an important characteristic of a medium of exchange during the period we are considering is debatable. On the one hand, according to Nigh (2013), the concern was minimal:

A question to consider is where was law enforcement [in curtailing counterfeiting prior the Civil War]? First, there was no national police force. Secondly, the federal government had the only constitutional authority to print money but 
there was never a challenge to the states' rights to charter banks and print its own currency. Monitoring the state's banking industry was sporadic at best. Thirdly, enforcement of counterfeiting laws was entirely local; many times local police looked the other way. Lastly, our economic system worked. We were a nation poor in gold and silver but desperate for credit and capital to satisfy our dreams and speculative nature. Counterfeit money picked up the slack.

On the other hand, the severity of some of the punishments for counterfeiting at the time shows that it was considered a serious problem. For example, the law against counterfeiting in Kentucky in 1822 states that ${ }^{7}$

Whosoever shall alter, forge, or counterfeit any bank bill, or bank note ... or shall tender in payment, utter, vend, exchange or barter any such altered, forged, or counterfeited bill or note ... knowing it to be such; or shall knowingly demand to have the same exchanged for ready money, with the intention to defraud; shall undergo a confinement in the jail and penitentiary, for any period not less than two years, nor more than ten years.

As some recent articles have mentioned, counterfeiting is still a concern today. For example, an article in the Wall Street Journal, 24 July 2000 states that

For shopkeepers who get caught holding the bag, fake money is a big deal. It raises transaction costs and reduces efficiency. Criminals often target businesses that can least likely afford it, such as convenience stores and mom-and-pop operations....

But all around there are signs that businesses are doing their best to cope. Some retailers have equipped their cashiers with special pens that are supposed to make a dark mark on a bill if it is a phony, and a light one if it is real. DriMark Products of Port Washington, N.Y., has seen sales of its Smart Money detector pen jump $20 \%$ over the past year. A three-pack of the pens retails for about $\$ 8$.

Further evidence of concerns about counterfeiting today is the enhanced security features in the redesign of the U.S. currency and the redesign of the Canadian currency to make counterfeiting more difficult.

The state bank note system did not perform well with respect to counterfeiting. Counterfeiting was rampant. According to Mihm (2007), "one newspaper editor bewailed in 1818: 'Counterfeiters and false bank notes are so common, that forgery seems to have lost its criminality in the minds of many.' " The huge amount of counterfeiting of bank notes was likely due to many reasons. One was the large number of issues scattered over a large geographical area. A second was the medium. Bank notes were printed on paper, although it was relatively high quality paper.

${ }^{7}$ A Digest of the Statute Law of Kentucky, volume II, Penal Laws, 1822: Part of an act passed December 22, 1802, in force from its passage (Sec. 9), p. 1000. Also, according to Mihm (2007, 123), "The courts meted out harsh punishment for the principals in the case. Ebenezer Gleason went first, tried on an outstanding indictment for counterfeiting state bank notes. For this crime alone he received a sentence of ten years hard labor - harsh by any standard." 
The pervasiveness of counterfeiting is shown in the information on bank notes published by brokers in many of the larger cities during the period. The phrase "Counterfeit Detector" was part of the title of many of them. For example, in Boston in the 1850s there was Clapp, Fuller, $\&$ Browne's Bank Note Reporter and Counterfeit Detector. In Cincinnati at the same time there was Lord's Detector and Bank Note Reporter. And in Philadelphia from at least the 1830s there was Van Count's Counterfeit Detector, and Bank Note List. In the remainder of this paper, I will refer to these publications as "Bank Note Reporters." Although Bank Note Reporters provided information about new counterfeits, this information occurred with a lag, since they were published only weekly, biweekly, or monthly. This information lag may have been a third reason that counterfeiting was rampant.

The pervasiveness of counterfeiting is shown in the Bank Note Reporters in two ways. Firstly, in virtually all of these publications, one of the early pages contained a list of new counterfeits. An example is shown in Figure 3. It shows part of the column "Counterfeits of the Month" from Thompson's Bank Note and Commercial Reporter, published from the 1840s to the 1860s in New York. Note the entry for the Webster Bank of Boston, Massachusetts: "better refuse all 5s."

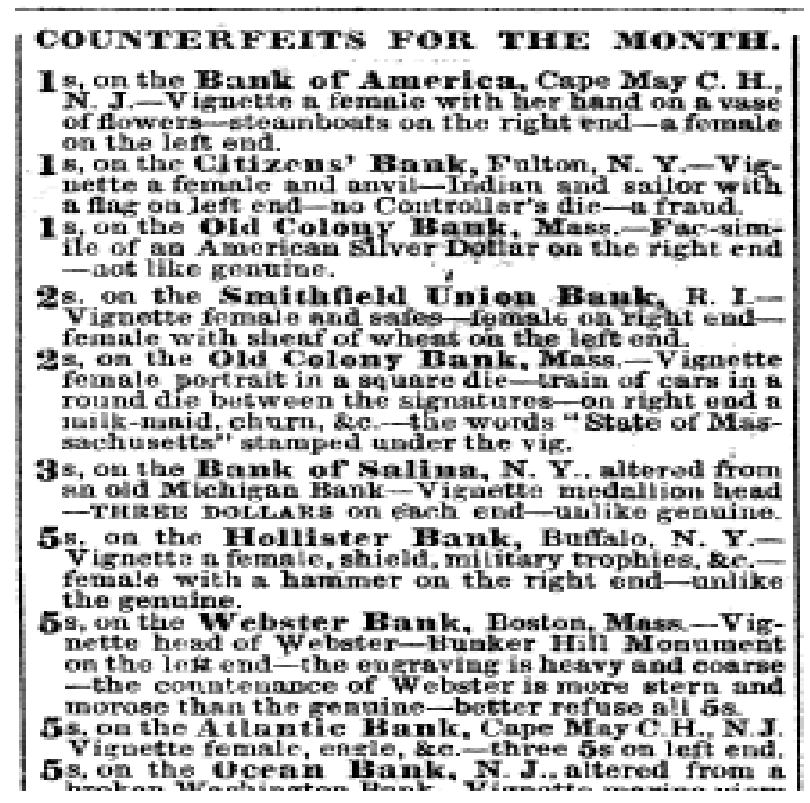

Figure 3: Listing of new counterfeit bank notes in New York, 1 January 1854

Secondly, in virtually all of these publications, the known counterfeits for a given bank were listed below the name of the bank. An example is shown in Figure 4, in which part of the listing for New York banks is taken from the same issue of Thompson's. The entries below each bank's name are the known counterfeits of the notes of that bank.

I checked all of the entries for New York banks in this issue of Thompson's, and found that 46 of the 58 banks (79\%) in that city had counterfeits listed for them. Further, counterfeiting was not just a problem in New York. It was a problem for banks everywhere in the country. There was not one state that did not have banks with counterfeits listed beneath it. In 


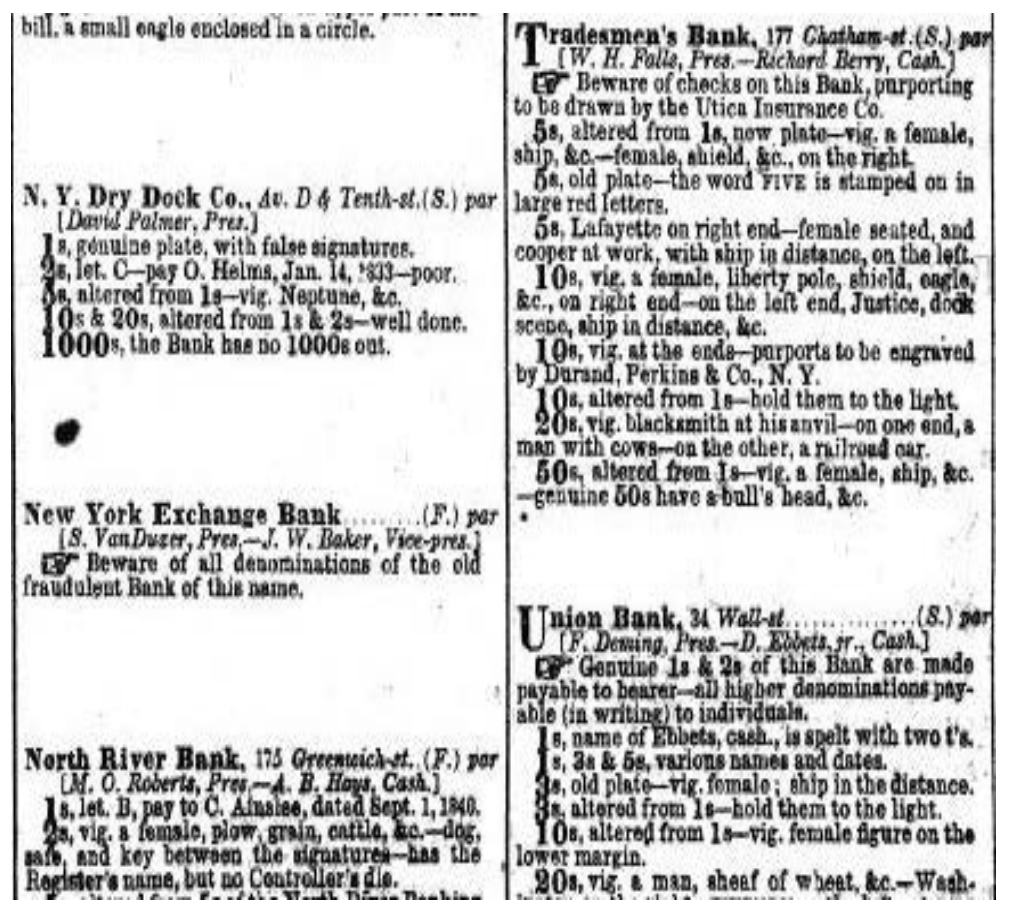

Figure 4: Partial listing of the counterfeits of New York bank notes, 1 January 1854

South Carolina, for example, 14 of the 19 banks in that state $(74 \%)$ had counterfeits listed for them.

There was a second aspect to the counterfeiting problem. Not only were notes of existing banks counterfeited, but there also were notes of banks that did not exist. Notice the entry for the New York Exchange Bank in Figure 4. It states, "Beware of all denominations of the old fraudulent [italics added] Bank of this name."

\subsection{Safety}

No financial asset will be considered a good medium of exchange unless it is able to store value well. This concern took three forms during the period of interest. The first was that because bank notes were bearer financial instruments, they would lose their entire value to the holder if lost or stolen. This concern was well expressed by Hildreth $(1840,140)$

Of all kinds of property, coin is the most exposed to the depredation of thieves. Its great value in a small bulk, the fact that it is money which serves at once, and without any further trouble, as a means of obtaining all other kinds of property, and its destitution of those ...tokens of recognition, which in the case of other kinds of property are apt to lead to detection, hold out peculiar temptations to the plunderer. Hence the great advantage of being able to carry a large sum of circulating medium about the person, and to carry it incognito... To carry money about in a bag is troublesome and dangerous; and if left at home it becomes a constant source of anxiety and alarm. From all these inconveniences, bank notes are in a great measure free. 
The second safety concern was the loss of value through use. Again, this concern is well expressed by Hildreth $(1840,141)$ who states that bank notes are a more desirable medium of exchange than coin because they "are free from that depreciation which arises from the wear and clipping of the current coin."

The third and by far the largest safety concern was whether the issuer of the bank note would be able to redeem it at par when the holder of the note wanted to redeem it for specie. As stated in a report to the New York legislature in 1837, "If a paper circulation is to be tolerated, it should be left, with proper guards as to its soundness, [italics added] ... to flow freely where it is wanted." 8

In terms of modern concerns about the safety of media of exchange, demand deposits are governmentally insured in most developed countries. The reason for providing such insurance was articulated by United States Representative Henry B. Steagall, one of the principal proponents of the establishment of the Federal Deposit Insurance Corporation (FDIC) in the United States. According to Steagall, the purpose of deposit insurance was to provide the public with "money as safe as though it were invested in a government bond" and to "prevent bank failures, with depositors walking in the streets." 9 More evidence of modern concerns about the safety of media of exchange is that in the United States on 19 September 2008, the U.S. Treasury announced the establishment of a temporary guarantee program to protect shareholders of money market mutual funds (MMFs), and on 29 September, it officially opened the program to eligible MMFs. Many MMFs were, and still are, providers of media of exchange in the sense that they allow check writing.

Because there are no data on the magnitude of losses on state bank notes due to theft or wear, I evaluate the safety of bank notes from the perspective of the losses to note holders from the failure of issuers to redeem their notes at par in specie.

The period I am considering was one of a large amount of turnover in financial institutions. At one time or another, 2,384 banks were in existence. However, at the end of 1860, only 1,439 banks were in existence; that is, 945 banks went out of existence during the period. Of the banks that went out of existence, at most 407 failed, in the sense that note holders lost when the bank went out of existence. ${ }^{10}$ Thus, if a bank went into business, there was a $17 \%$ chance (maximum) that it would end up failing with losses to note holders, and if a bank went out of business there was a $43 \%$ chance (maximum) that its note holders would suffer a loss.

More perspective is obtained by looking at failures on a yearly basis. In Figure 5, I plot the number of state bank failures by year from 1810 to 1860 . The reason for beginning with 1810 is that there were no failures before 1812. The figure shows that the majority of failures (318 out of 407) were concentrated around three time periods: 1818-1821, when there were 36 failures; 1838-1842, when there were 142 failures; and 1854-1860, when there were 140 failures.

${ }^{8}$ Documents of the Senate of the State of New-York, Sixtieth Session, 1837, volume II, No. 55, 18 March, p. 17.

${ }^{9}$ New York Times 21 May 1933, and 14 June 1933.

${ }^{10}$ I say at most, because there are many banks for which I cannot determine whether note holders lost when the bank went out of existence. I classify these banks as failed if they are listed as failed in Haxby (1988). However, I am not certain of the criteria that Haxby (1988) uses to classify a bank as a failure. It could be that he does so if there were losses to depositors or shareholders but not to note holders. 


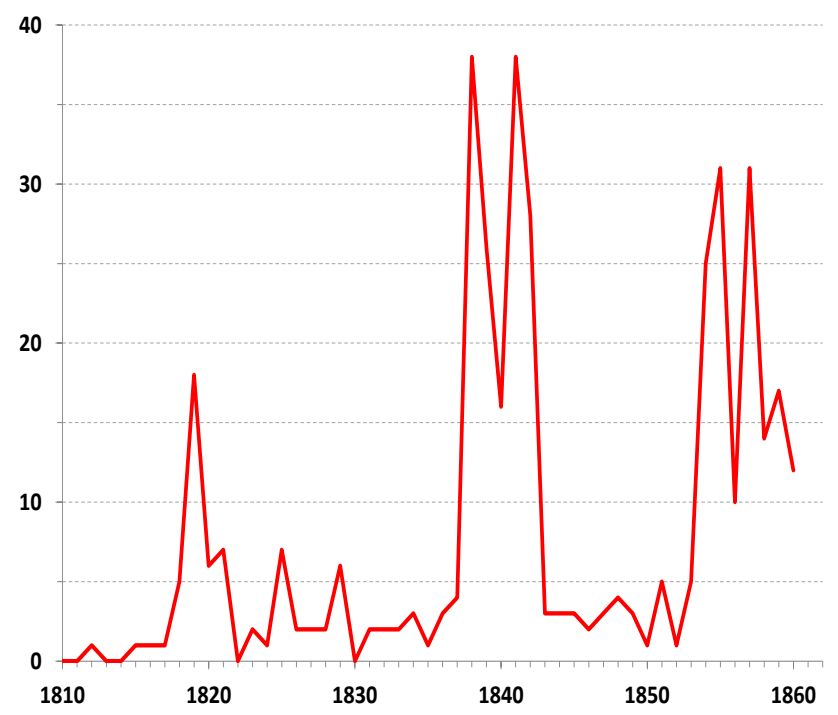

Figure 5: Number of state bank failures by year, 1810-1860

These three periods have several features in common. All three were periods of financial distress. There was a banking panic in 1819. There was severe recession that began in 1837 and lasted until 1842. There were mild banking panics in 1854 and 1857, and the financial distress associated with the Civil War could be seen beginning in 1860 .

Additionally, all three of these periods of large numbers of bank failures were also periods of marked changes in bank chartering and regulation, and many of the banks established under the new charters and regulations failed shortly after going into business. Some examples:

- 1818-1821 Pennsylvania passed an act chartering 41 banks in March 1814. I have been able to determine that 37 of these banks went into business. Twelve of these went out of business by the end of 1821, with five of them failing and note holders suffering losses. Kentucky did a similar mass chartering of banks. Prior to 1818, Kentucky had only one bank. In January 1818, the legislature passed "The ACT to establish Independent Banks in this Commonwealth" that enabled the chartering of 40 banks, although I have only been able to find evidence that fifteen banks actually went into operation. At least thirteen of these banks failed (I cannot determine whether the other two failed or simply closed), and all fifteen went out of business on or before December 1819.

- 1838-1842 Michigan passed the first free banking act in 1837. Forty-two free banks were established under this law. ${ }^{11}$ Also, six chartered banks went into existence. Thirty-eight of these 48 banks failed. New York passed a free banking act in 1838,

\footnotetext{
${ }^{11}$ The number may actually be 48 , since there are six free banks that went into business in Michigan whose beginning and ending dates I have been unable to determine. All six of these banks failed.
} 
and by April 1841, 82 free banks had been established under the law. Of these, 23 failed during this period. Another nine chartered banks in New York also failed during this period.

- 1854-1860 Indiana passed a free banking law in 1854. Ninety-five banks were established under it, 41 of which failed during this period.

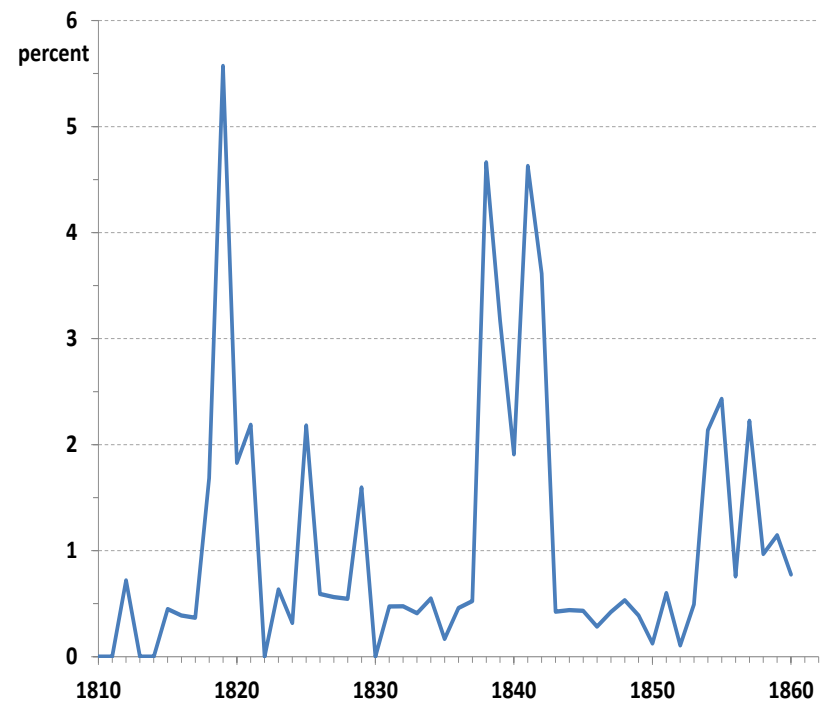

Figure 6: Rate of state bank failures by year, 1810-1860

The 407 bank failures during the period I am considering might seem like a high number of failures. To get a broader perspective I will consider three additional pieces of information. The first is failure rates, reported in Figure 6. The spikes in failures associated with the three periods mentioned above are clearly indicated. The highest failure rate was $5.6 \%$ in 1819 . In no other year was the failure rate greater than $5 \%$. Further, in almost half of the 50 years between 1810 and 1860, the failure rate was $0.5 \%$ (1 in 200) or less.

The second piece of information about the safety of state bank notes is how good they were as stores of value. Rolnick and Weber (1983) looked at this for banks formed under free banking laws in New York, Wisconsin, and Indiana. They calculated the expected loss that the holder of a representative bank note would have had if the note had been held until 1863. ${ }^{12}$ Their results are reported in Table 2.

The table shows that the losses on a representative note were always small in New York. In Wisconsin, the losses on a representative note were initially small, but increased over time as the value of the state bonds of southern states which were the backing for the notes of

\footnotetext{
${ }^{12}$ Specifically, for each date they multiplied the notes of a bank by one if the bank was in existence in 1863, and by the redemption rate if the bank failed before 1863. Then they added these results together and calculated the expected loss as one minus the value of the ratio of this number to the total number of notes.
} 


\begin{tabular}{rrrr} 
Year & New York & Wisconsin & Indiana \\
1843 & 0.3 & & \\
1844 & 0.2 & & \\
1845 & 0.1 & & \\
1846 & 0.1 & & \\
1847 & 0.2 & & \\
1848 & 0.7 & & \\
1849 & 0.2 & & \\
1850 & 0.2 & & \\
1851 & 0.1 & & \\
1852 & 0.1 & & \\
1853 & 0.1 & 0 & 7.8 \\
1854 & 0 & 0 & 5.1 \\
1855 & 0 & 0.9 & 0.3 \\
1856 & 0 & 1.7 & 0.3 \\
1857 & 0 & 3.6 & 0.8 \\
1858 & 0 & 6.4 & 1.1 \\
1859 & 0 & 7.2 & 1.1 \\
1860 & 0 & 10.4 & 1 \\
\hline
\end{tabular}

Table 2: Expected loss (in percent) on a representative bank note held until 1863

some of these banks fell in value as the Civil War approached. In Indiana, losses were large initially, but were small after 1855 as the system of free banking stabilized in that state.

The third piece of information about the safety of state bank notes is the losses suffered by note holders if they were holding notes of a bank that failed. Getting such information for chartered banks is difficult. I have relied primarily on the computations of losses done by Root (1901). For free banks that failed, more information is available from the state authority, which posted the redemption rates once they sold the state bonds backing the notes. The redemption information is reported in Table 3. The table shows that, in general, note holders lost between 13 and 40 percent of the par value of the notes if the bank failed. However, in three states - Maine, Minnesota, and Vermont - the losses were much larger. ${ }^{13}$ The experience also varied widely by bank. For example, for two banks, one in Indiana and one in New York, the redemption rates were 0.97 , so that holders of notes of those banks suffered only a 3 percent loss. In contrast, for one bank in Vermont, the holders of its notes lost almost all their value (the loss was 96 percent) when that bank failed.

There is a sense, however, in which these redemption rates understate the losses suffered by note holders. These are the rates at which the notes were ultimately redeemed, which could be some time after the bank failed. If the holder of a note wanted to immediately

\footnotetext{
${ }^{13}$ Rolnick and Weber (1988) argue that there are reasons to believe the notes issued by Minnesota free banks were not issued at par, but substantially below par. If this is the case, the losses on Minnesota bank notes would not be nearly as large as shown in Table 3. This is also the reason that the computations for Minnesota are omitted from Table 2.
} 
convert it to specie, it is likely that the note would be discounted by brokers by more than what is indicated in Table 3.

\begin{tabular}{lrrrrrr}
\multicolumn{1}{c}{ State } & Failures & $\begin{array}{r}\text { Redemption } \\
\text { information }\end{array}$ & Minimum & Maximum & Average & Median \\
Connecticut & 7 & 2 & 0.63 & 0.80 & 0.72 & 0.72 \\
Illinois & 12 & 4 & 0.53 & 0.94 & 0.75 & 0.76 \\
Indiana & 43 & 24 & 0.69 & 0.97 & 0.87 & 0.89 \\
Maine & 19 & 9 & 0.06 & 0.81 & 0.54 & 0.52 \\
Massachusetts & 12 & 3 & 0.31 & 0.94 & 0.67 & 0.76 \\
Maryland & 14 & 1 & 0.84 & 0.84 & 0.84 & 0.84 \\
Michigan & 54 & 7 & 0.10 & 0.95 & 0.47 & 0.41 \\
Minnesota & 9 & 9 & 0.16 & 0.98 & 0.37 & 0.21 \\
New Hampshire & 4 & 1 & 0.60 & 0.60 & 0.60 & 0.60 \\
New York & 54 & 33 & 0.25 & 0.97 & 0.72 & 0.75 \\
Rhode Island & 11 & 4 & 0.60 & 0.79 & 0.67 & 0.65 \\
Vermont & 5 & 3 & 0.04 & 0.81 & 0.46 & 0.52 \\
Wisconsin & 3 & 1 & 0.93 & 0.93 & 0.93 & 0.93
\end{tabular}

Table 3: Minimum, maximum, average, and median redemption rates on bank notes for banks that failed

\subsection{No overissuance}

The term "overissuance" can have two meanings when applied to a medium of exchange. One meaning is that a bank is issuing demand liabilities in an amount greater than the assets it has available to redeem them. This type of overissuance was covered in section 4.3. A bank that was overissuing in this way would not be able to redeem its notes at par.

The second meaning of the term "overissuance" is that the issuer of a medium of exchange is issuing it at too great a rate. Limitations on the rate of growth of the supply of a medium of exchange are essential if it is to be valued or if it is to maintain its value over time. This is the case with any medium of exchange even if it is perfectly safe or fiat.

The concern that overissuance of bank notes could reduce the value of bank notes specifically and of all media of exchange generally was well expressed in an 1838 report to the New York legislature: ${ }^{14}$

After the first flood of paper money is poured out, prices begin to rise; and the illusions of deceitful prosperity are manifested. By the rise of prices and prospect of gain, avarice and cupidity are stimulated. Individuals begin to purchase more largely and sell at greater profits. Others are tempted into the market and new issues of paper are made.

\footnotetext{
${ }^{14}$ Documents of the Senate of the State of New-York, Sixty-first Session, 1838, volume II, No. 68, 9 April, p. 23.
} 
The 1838 Report (p. 30) continued, "We know that banks vested with the powers of inflating the currency ... will ... often inflict this dreadful evil on the community." 15

That this is still a concern today can be seen in the revision to the Federal Reserve Act of 1977, which makes price stability one of the goals of the Federal Reserve System in the United States: ${ }^{16}$

The Board of Governors of the Federal Reserve System and the Federal Open Market Committee shall maintain long run growth of the monetary and credit aggregates commensurate with the economy's long run potential to increase production, so as to promote effectively the goals of maximum employment, stable prices, and moderate long-term interest rates. (Section $2 \mathrm{~A}$ )

Further, today many central banks have committed to inflation targeting and are quite successful in gaining public confidence. If overissuance is a concern, it should be less a problem for central banks that have gained a reputation for keeping inflation low and stable.

Overissuance did not seem to be a problem with bank notes. To determine this, I first examine whether changes in prices were correlated with bank note issuance. Since data on the quantity of bank notes in existence are somewhat limited and problematic, I do this in two ways. First, I look at the relationship between the rate of inflation and the rate of change in the quantity of bank notes in existence as estimated by Rutner (1974). This is shown in Figure 7. The beginning of the time period is determined by the period for which the Rutner (1974) data exist.

The figure shows that there is not a strong relationship between inflation and the rate of creation of bank notes; the correlation is only 0.53 .

To obtain more evidence on the relationship between inflation and the rate of creation of bank notes, I run a VAR of inflation and the growth of bank notes with one lag of each. That there is not a strong relationship between inflation and rate of creation of bank notes is shown by the small response of inflation to an innovation in the growth of bank notes shown in Figure 8. ${ }^{17}$ Specifically, the response of inflation to a one standard deviation innovation in bank note growth (14.2 percent) is only slightly greater than 2 percent and it completely disappears after two periods.

Even more evidence that there is not a strong relationship between inflation and the rate of creation of bank notes is given by the fact that the periods with a large growth in the quantity of bank notes did not exhibit much inflation. This is the case even if the focus is only periods when there was a large increase in the quantity of bank notes. Specifically, there was a large increase in bank notes between 1838 and 1839, but no inflation over that period. The period from 1843 to 1847 was also one of a strong growth in bank notes, yet inflation only averaged 2.7 percent over that period. And the 1850 s were a period of strong growth in bank notes (5.7 percent on average from 1849 to 1860). Yet, inflation averaged only 0.8 percent over that period.

\footnotetext{
${ }^{15}$ The report (p. 30) also has this observation: '"Experience,' says Ricardo, 'shews that neither a State nor a bank ever have had the unrestricted power of issuing paper money, without abusing that power.' "

${ }^{16}$ The Fed is usually said to have a dual mandate, but this revision makes it seem like the Fed has a triple mandate, with "moderate long-term interest rates" being the third part.

${ }^{17}$ The dashed red lines are two standard deviation confidence intervals around the response function.
} 


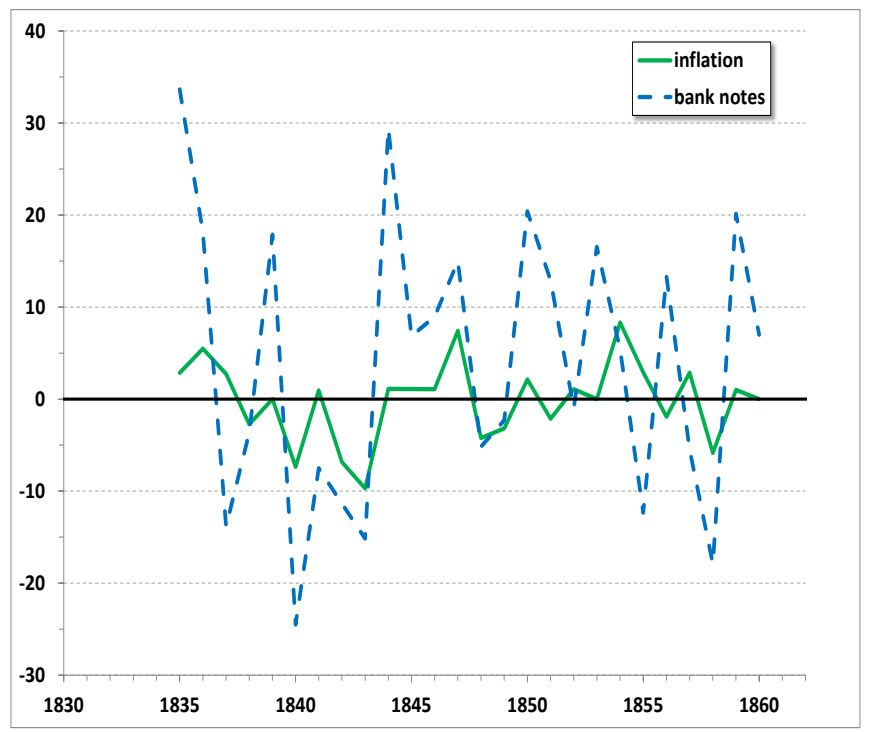

Figure 7: Inflation and the rate of growth of bank notes, 1835-1860

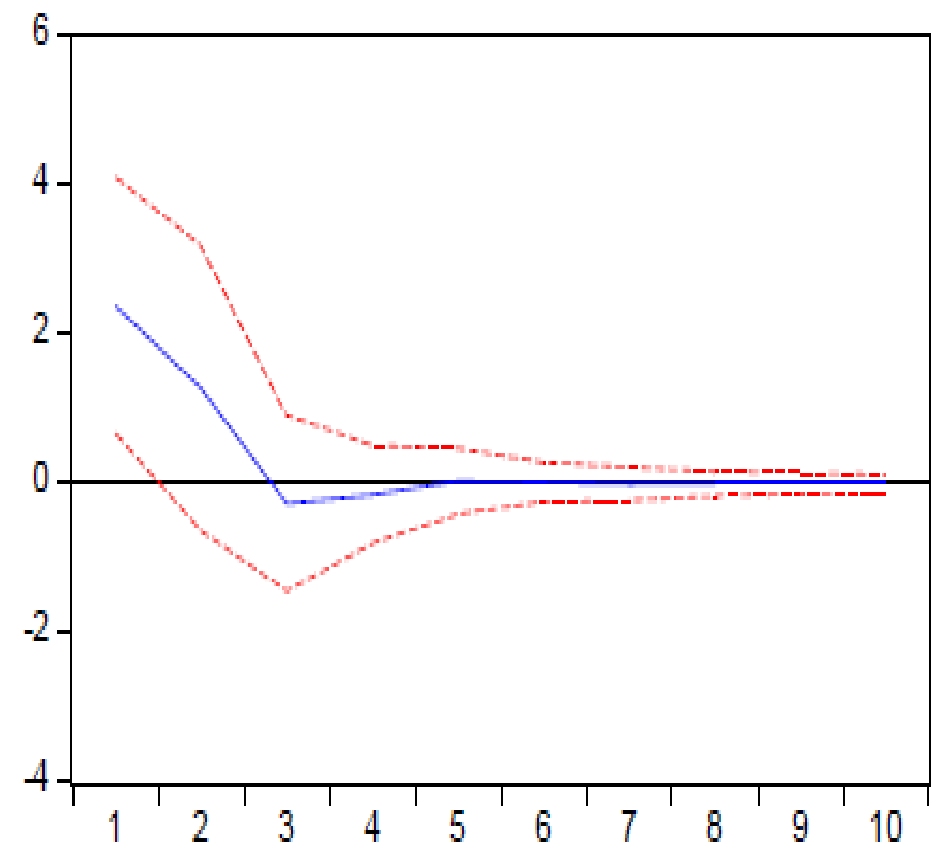

Figure 8: Response of inflation to a one standard deviation in the rate of growth of bank notes 
Given the limitations of the Rutner (1974) data, I also examine the relationship between inflation and the growth rate of the number of banks. This is shown in Figure 9. Although I have data on the number of banks beginning in 1784, I only consider the period beginning in 1800, since the number of banks before then was small, so that growth rates were quite large and quite volatile.

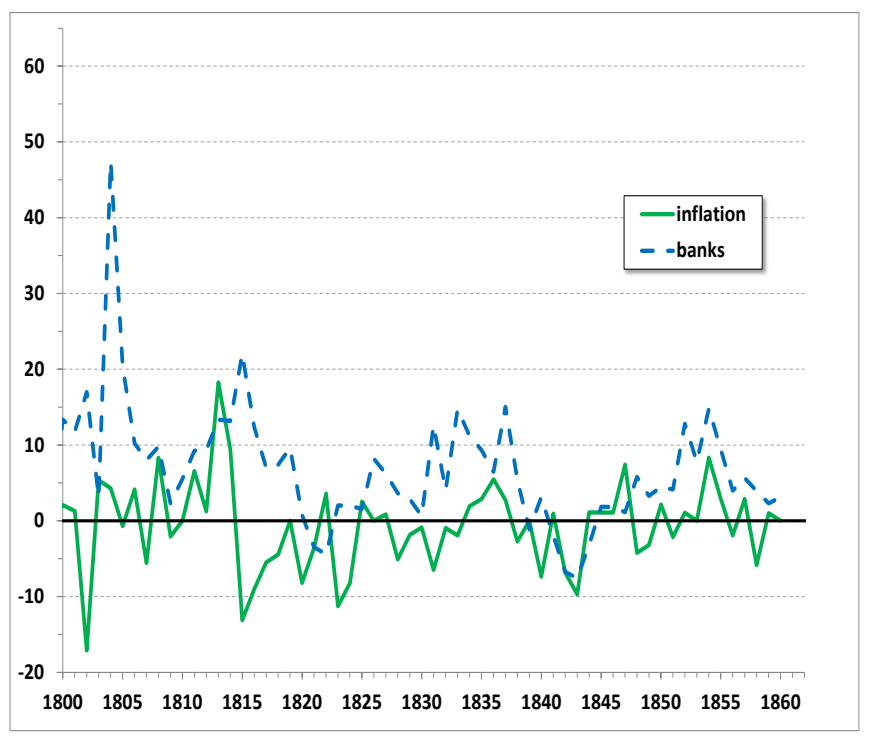

Figure 9: Inflation and the growth rate of the number of banks, 1800-1860

The figure shows that there is also not a strong relationship between inflation and rate of creation of banks; the correlation is only $0.16 .^{18}$

To obtain more evidence on the relationship between inflation and the rate of creation of bank notes, I ran a VAR of inflation and the growth in the number of banks. That there is not a strong relationship between inflation and rate of creation of banks notes is shown by the small response of inflation to an innovation in the growth of banks shown in Figure 10. Specifically, the response of inflation to a one standard deviation innovation in bank growth (7 percent) appears with a one year lag and is slightly less than 1 percent. The effect completely disappears after three periods. That the effect of bank growth on inflation occurs with a one year lag may be due to the fact that it took banks some time to get notes into circulation after they went into business. ${ }^{19}$

Further, the lack of a relationship between growth in the number of banks and inflation holds even if the focus is only periods when there was a large increase in the number of banks. Specifically, between 1810 and 1819 there was an average increase of 11.5 percent in the number of banks, but inflation averaged only 0.8 percent. There was another large increase in the number of banks between 1825 and 1837 (7.9 percent, on average), but this

\footnotetext{
${ }^{18}$ The correlation over the period 1835 to 1860 is 0.53 , the same as for bank notes. Interestingly, however, there is no correlation between the rate of growth of banks and the rate of growth of bank notes over that period. The correlation between the two is only 0.02 .

${ }^{19}$ I also ran this VAR on the shorter sample period 1835 to 1860 . The results were qualitatively the same.
} 


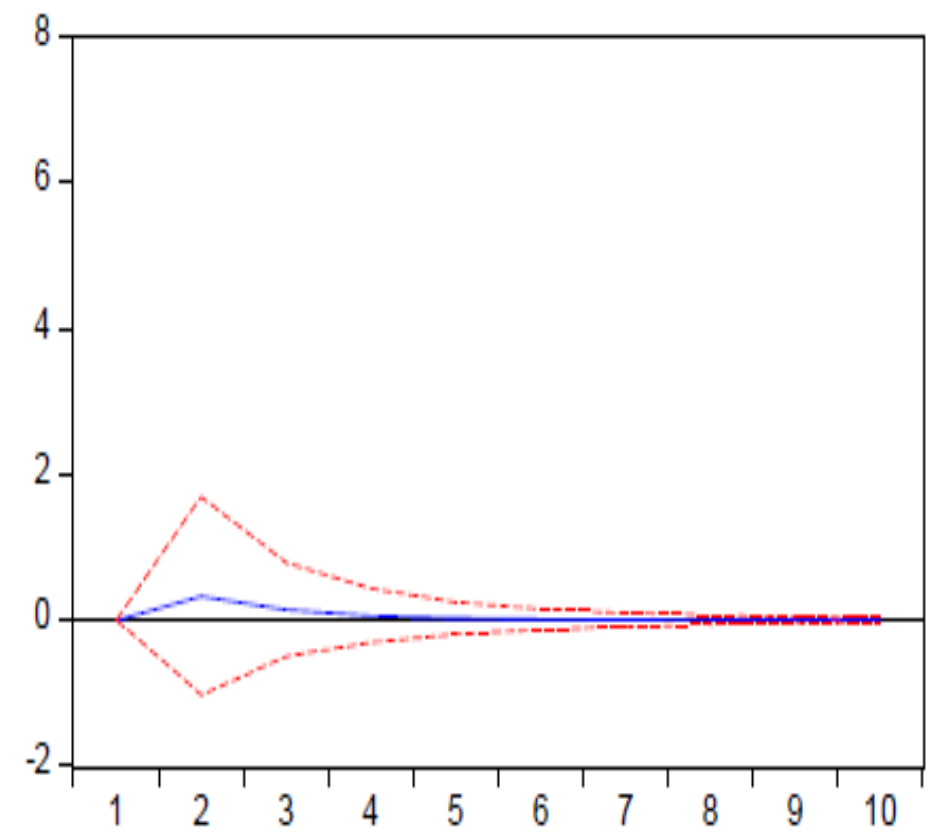

Figure 10: Response of inflation to a one standard deviation in the rate of growth of banks

was a period of a slight deflation. Prices fell by 0.2 percent, on average. And between 1848 and 1855 the number of banks increased by 7.8 percent per year, on average. This was a period of even greater deflation: -3.0 percent per year, on average.

\subsection{Par exchange}

In order to discuss whether par exchange is desirable for media of exchange, it is necessary to define exactly what is meant by the term. I will define par exchange to mean that the media of exchange of all issuers, regardless of their location, always exchange one-for-one with the media of exchange issued by all other issuers, regardless of their location, and regardless of the location in which the exchange takes place. As an example, par exchange would mean that the notes of banks located in New York City would exchange one-for-one with notes of banks located in Cleveland regardless of where the exchange took place. That is, they would exchange one-for-one whether the exchange took place in New York City, Cleveland, or some other location, say Philadelphia. ${ }^{20}$

Although the following quotation from Bankers' Magazine in 1898 is not exactly contemporary to the period, it aptly summarizes the feelings at the time about par exchange: ${ }^{21}$

\footnotetext{
${ }^{20}$ Note that to make the case for par exchange one must go beyond the case for having fixed exchange rates rather than floating rates. One must make the case that the exchange rate be fixed and equal to unity. On this point, Rolnick $(1999,675)$ argues, "Although some might argue that nonpar circulation of private currencies is not a problem, achieving a uniform currency has historically been thought to be an important element of a well-functioning economy."

21 "Banking as it Relates to Industrial Development," Bankers' Magazine, 57(1898): 498.
} 
That there has been great progress, in our system of banking, in the past halfcentury, none will deny; and that we have the satisfaction of seeing every dollar of currency worth a dollar of gold, every day we live, is an evidence of that progress. Many there are in this audience who can easily remember the uncertainties which surrounded commercial enterprizes and industrial development not so many years ago, when in every business house there hung a Thompson or Dye's Bank Note Reporter, giving the latest quotations of discounts on the constantly fluctuating currency with which our country was flooded. It was utterly impossible for a business man at that time to tell the profit on a transaction, for by the time such money had circulated, to any great extent, it might have fallen or risen in value from ten to twenty percent.

The desirability of par exchange today can be seen in the pressure to have checks cleared at par and the arguments to replace the individual sovereign currencies in Europe with the euro. With regard to par check clearing (Connolly and Eisenmenger, 2000, 132-133):

When Congress created the Federal Reserve System in 1913, more than 25,000 independently chartered banks were operating in the United States... . Furthermore, 40 percent of all banks were "nonpar" institutions, which meant that they imposed an "exchange charge" on the payment for each check submitted to them for collections by banks outside their local trading area, effectively making the check worth less than its face value.

To avoid these charges, collecting banks generally tried to send each nonpar check to a correspondent bank that had a reciprocal check-clearing arrangement with the nonpar institution on which the check was drawn. The practical result, unfortunately, was substantial circuitous routing of checks, which added time and confusion to the check collection process. By the time a check finally arrived at a paying nonpar institution, days and even weeks might have elapsed. By then, the balance in the check writer's account had sometimes disappeared.

The Congress was aware of the banking industry's failed check collection system, and this was on of the reasons it passed the Federal Reserve Act in 1913.

The benefits of the euro, according to Mundell (1998), are that "Europeans will gain a currency that spans a continent. The benefits will derive from transparency of pricing, stability of expectations and lower transactions costs."

Note also that Visa and MasterCard require that merchants who accept their cards not give discounts for cash. However, the fact that many credit cards give "loyalty points" for purchases means that they do not exchange at par with cash. Also, merchants can be charged different discount fees for accepting credit cards. Some cards (e.g., premium cards) have a higher fee than others. Thus, for a merchant, a dollar paid with one card may not be the same as a dollar paid with another card.

Notes of one state bank generally did not exchange with those of other state banks at par. This is obvious when looking at any of the numerous Banknote Reporters published during the period. An example is shown in Figure 11, which reports the discounts on the notes of several Pennsylvania banks in New York. The quoted discount is the rate at which 
the broker is willing to exchange notes of banks in the city in which the broker is located for notes of the listed banks. The figure shows that discounts vary by the location of the issuing bank, which may partially reflect the cost of taking notes from New York to the issuer for redemption in specie. ${ }^{22,23}$

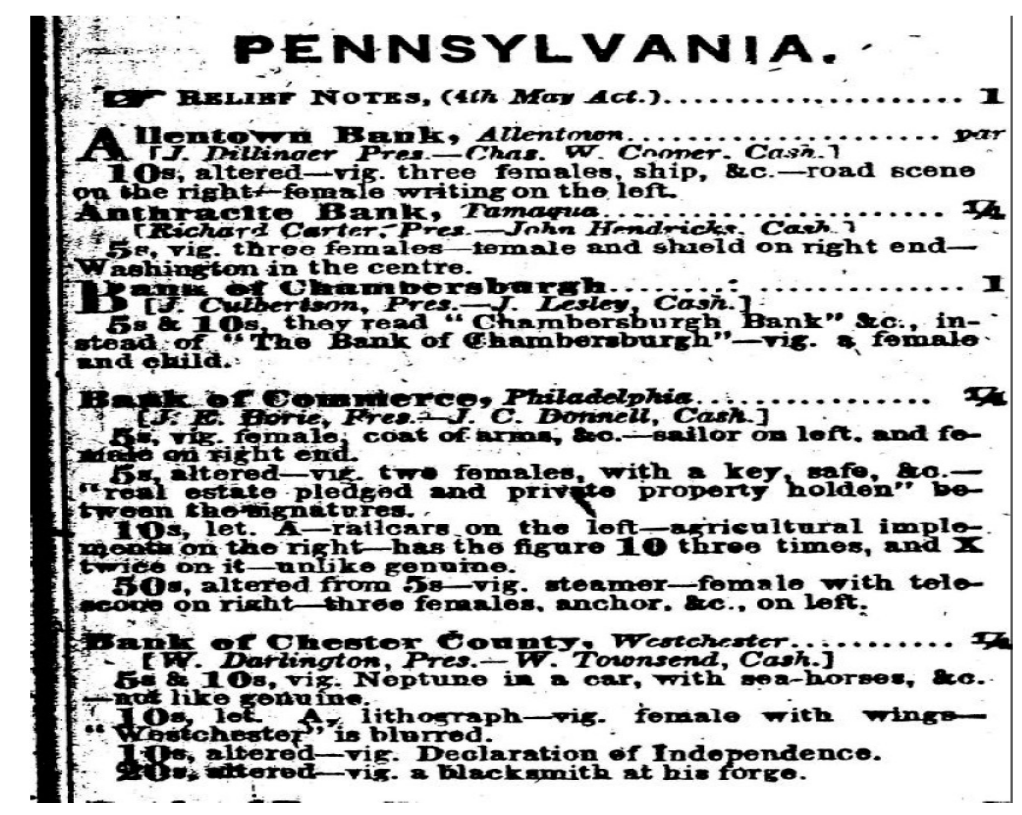

Figure 11: Listing of discounts on selected Pennsylvania bank notes in New York, 1 January 1854

The discounts on notes fluctuated over time. Figure 12 plots the discount on the notes of the Bank of South Carolina located in Charleston, South Carolina as quoted in New York (blue line) and in Philadelphia (red line) from 1840 to 1860. The fluctuations in the discount on the notes of this bank in those two locations are clearly shown. The figure also shows that changes in the discount occurred quite often.

The figure shows two other features of bank note discounts. The first is that discounts on the notes of a given bank were not the same across locations. For example, the figure shows that the discounts on the notes of the Bank of South Carolina were almost always larger in New York than they were in Philadelphia. The second is that discounts quoted in different locations did not always move at the same time or in the same direction. For example, in the figure there are numerous times when the discount moves up (down) in one location and stays the same or moves down (up) in the other. The correlation between the discounts shown in Figure 12 is only 0.57.

\footnotetext{
${ }^{22}$ I say partially because Ales, Carapella, Maziero, and Weber (2008) observe that bank note discounts were asymmetric. For example, the discount on the notes of Cleveland banks in New York was larger than the discount on New York bank notes in Cleveland. They argue that this asymmetry means that more than mere redemption costs were involved in determining the amount of the discount on a bank's notes.

${ }^{23}$ It may seem strange that the notes of the Allentown Bank went at par in New York. The reason was that this bank had a New York correspondent with which it maintained an account for the redemption of its notes.
} 


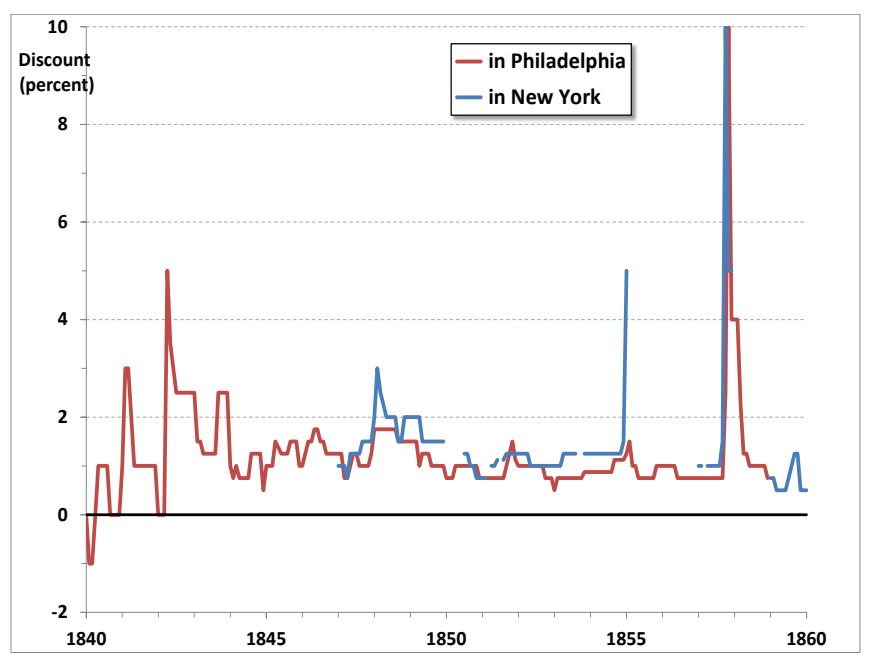

Figure 12: Discounts on the notes of the Bank of South Carolina quoted in New York and Philadelphia, 1840-1860

Not only did the discount of the notes of a given bank differ by where the discount was quoted, but the discount on notes quoted in a given location depended on the bank. This is shown in Figure 13, where I plot the discount in Philadelphia on the notes of the Suffolk Bank, located in Boston, and the Bank of South Carolina from 1830 to 1858. The discounts on the notes of the Suffolk Bank are uniformly lower than those on the notes of the Bank of South Carolina. Further, the movement of the discounts is not highly correlated; the correlation is only 0.33 .

Figure 13 also shows the important role that bank suspensions played in the determination of the discount on the notes of a bank. From mid-1839 through 1842, the notes of the Suffolk Bank were quoted at a negative discount (a premium) in Philadelphia. The reason is that, during this period, banks in Philadelphia had suspended the payment of specie on their notes, whereas the Suffolk Bank was redeeming its notes in specie. This ability to obtain specie for Suffolk Bank notes made them more valuable in Philadelphia than notes of banks of that city. There was also a short time in early 1840 when the Bank of South Carolina was not suspended but Philadelphia banks were, and its notes were also quoted at a premium in Philadelphia.

The effect of the bank panic in the fall of 1857 is also shown in Figure 13 by the spike in the discount on the notes of the Bank of South Carolina at that time. However, Suffolk Bank notes went at a premium once again at that time, presumably reflecting greater confidence that it would not suspend but that banks in Philadelphia might. ${ }^{24}$

There were two schemes put in place during this period that resulted in the par exchange

\footnotetext{
${ }^{24}$ Contributing to the uncertainty in Philadelphia at that time was the failure of the Bank of Pennsylvania, located in Philadelphia. The Bank of Pennsylvania was a bank with a large circulation. It also served as a correspondent for several Pennsylvania banks before its failure.
} 


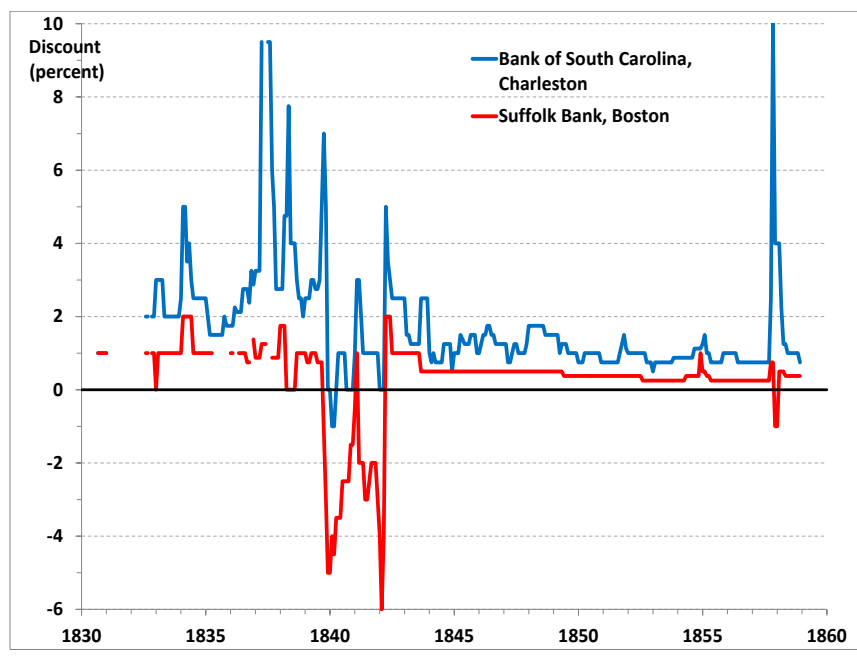

Figure 13: Discounts on the notes of the Suffolk Bank and the Bank of South Carolina in Philadelphia, 1830-1858

of the notes of different banks throughout a state or over a large geographic region. These instances will be relevant to the discussion in the next section.

The first of these schemes was the Suffolk Banking System (SBS). The SBS was a bank note clearing system that existed in New England between 1825 and 1858. It was operated by a single bank, the Suffolk Bank in Boston. The SBS worked as follows: member banks were required to keep an interest-free deposit at the Suffolk Bank (or at one of the other Boston member banks) of 2 percent of capital. These accounts acted very much like the member bank reserve accounts operate at the Fed today. Every day, the Suffolk Bank accepted and net cleared all the bank notes its members deposited at par. If a bank had a net positive position, then the Suffolk Bank credited that bank's account with it. It debited the accounts of banks with net negative positions. A large value of notes was clearing through the SBS each month.

The net clearing of notes at par was the innovation of the SBS. The result was that notes of member banks circulated against each other at par in New England, although they did not circulate at par against those of banks located outside of New England.

The second of these schemes that resulted in the par exchange of bank notes were the systems that went under the name of "State Bank of ...." The first of these schemes was the State Bank of Indiana, which operated from 1834 until 1857, when it ceased doing business before its charter expired in 1859. ${ }^{25}$ The second of these schemes was the State Bank of Ohio, which began in 1845 and lasted until 1863, when its branches converted to national banks. The State Bank of Iowa started operations in 1858 and lasted until 1863. The banks that were members of the systems were called branches. Thus, for example, the bank in Indianapolis, Indiana that was a member of the State Bank of Indiana system was called the

\footnotetext{
${ }^{25}$ It was replaced by the Bank of the State of Indiana, which was a similar system.
} 
"Indianapolis Branch of the State Bank of Indiana."

Despite being called branches, the member banks of these systems were not really branches of a parent bank but were independent banks. Each branch had its own stockholders, issued its own distinct notes that were redeemable only at that branch, and distributed profits (paid dividends) only to stockholders of that branch. The entity known as the "State Bank of ..." did no actual banking business whatsoever.

The feature of these "State Bank of ..." systems that led to the notes of the various branches to exchange at par was what I will call "required par acceptance." Branches were required to accept the notes of all other branches at par. That is, a branch was required to accept the notes of other branches at par for payment of debts. Branches were not required to redeem the notes of other branches for specie, however.

\section{Regulation and the experience with state bank notes}

As the discussion at the end of the previous section shows, in terms of the desirable characteristics of a media of exchange, state bank notes fell short on almost all of them:

- Ease of transacting: Bank notes made transacting easier than coin, the other medium of exchange at the time, but suffered from two drawbacks. The first was that they were large denomination. The second is that their denomination structure led to difficulties in making change.

- Minimal counterfeiting: Bank notes definitely failed miserably in this regard, as counterfeiting was rampant.

- Safety: Bank notes were not perfectly safe, in the sense that note holders suffered losses due to the failure of some banks. However, the losses to note holders due to bank failures in most cases were not huge.

- No overissuance: This did not seem to be a problem with bank notes.

- Par exchange: In general, the notes of different banks did not exchange at par. And the notes of a given bank usually exchanged at different rates in different locations. The exceptions were notes of banks that were in the same local area (or, in a couple of instances, of banks in the same state), and banks that were members of the SBS and the branches of the State of Indiana, the State Bank of Ohio, and the State Bank of Iowa.

In this section I examine the extent to which the shortcomings of bank notes can be attributed to the regulations under which the system operated. I then discuss the extent to which the shortcomings of the bank note system can be expected to occur with e-money, and use this discussion to consider whether there are regulations that could or should be enacted to mitigate the shortcomings that can be expected with e-moneys. 


\subsection{Ease of transacting}

The difficulty with using bank notes in transactions was their denomination structure. The difficulty in making change with bank notes was largely a consequence of regulation; namely, the minimum-denomination restrictions contained in virtually all bank charters and contained in all free banking laws.

However, the necessity of making change is inherent in any currency system with only a finite number of denominations. If the quantity of a particular denomination that is useful in making change is in short supply or does not exist, as with the $\$ 13$ note issued by the Phenix Bank mentioned in section 4, then making change becomes very inconvenient.

Obviously, this will not be a problem for e-moneys, regardless of the issuer, since deductions from them (payments) could be in any amount. Another way of stating this is that they can be "issued" in a countably finite number of denominations, as with demand deposits today. Hence, there will never be a problem with making change. Thus, there is no need for regulation to make e-moneys easy to transact with.

\subsection{Minimal counterfeiting}

There is a sense in which the counterfeiting of state bank notes can be said to have been partially a failure of government. If the argument and evidence given above by Nigh (2013) are correct, there was lax enforcement of anti-counterfeiting laws. Further, there were no governmental regulations enacted with regard to how state bank notes were designed or printed to make counterfeiting less prevalent. Any measures taken were taken by the issuers (Mihm (2007)):

The banks fought back [against counterfeiters], commissioning ever more elaborate notes that contain many of the same anticounterfeiting features that survive today: special inks, watermarks and proprietary paper recipes. Engravers also sought to create ever more elaborate, intricate designs that would defy imitation.

Counterfeiting will be a problem with any medium of exchange, be it commodity or fiat; coin, paper, or electronic; governmentally-issued or privately-issued. ${ }^{26}$ Counterfeiting is attractive because the value of a financial instrument when it is a medium of exchange is greater than its intrinsic value. History also shows that counterfeiting will occur even when the punishments for counterfeiting are extreme. As an example, the royal accounts for France in 1311 show:

- 27L 4s to Master Henri, for boiling counterfeiters.

- 100s for the purchase of a cauldron to boil counterfeiters in Montdidier.

- In Paris, 38s to repair a cauldron and affix iron bars.

\footnotetext{
${ }^{26}$ According to Dillistin $(1949,10)$, "There are reports of counterfeiting of paper currency in China as early as the eleventh century, so that it is not surprising that soon after paper money appeared in this country it was counterfeited."
} 
E-moneys are no different from other moneys in this regard: they will be subject to counterfeiting and hacking. The implication is that the regulation of e-moneys will require strong laws and enforcement policies. It will also be important for regulators to encourage investment in strong security features, and to encourage co-operation between private emoney issuers to set minimum security features for their e-money products. ${ }^{27}$

\subsection{Safety}

That banks failed during the period shows that the regulations enacted to promote state bank note safety were inadequate. There were two types of such regulations. One was free banking laws. Banks established under these laws were required to back their notes $100 \%$ or more with state bonds. According to Redlich (1968, 36-36), the idea for this requirement goes at least as far back as David Ricardo's Proposals for an Economical and Secure Currency. Ricardo wrote:

What objection can there be against requiring of those who take upon themselves the office of furnishing the public with a circulating medium, to deposit with government an adequate security for the due performance of their engagements... . those whose habits and pursuits are little suited to explore the mechanism of trade are obliged to make use of money, and are no way qualified to ascertain the solidity of the different banks .... Accordingly we find that men living on limited incomes, women, labourers, and mechanics of all descriptions, are often severe sufferers by the failures of country banks... . Against this inconvenience the public should be protected by requiring of every country bank to deposit with government ... funded property or other government security, in some proportion to the amount of their issues.

Redlich $(1969,191)$ asserts that Ricardo "undoubtedly derived his inspirations from the note issue privilege of the Bank of England." 28

${ }^{27}$ The payment card industry has established the Payment Card Industry Data Security Standard, a proprietary information security standard for organizations that handle cardholder information for the major payment cards.

${ }^{28}$ Redlich (1968) goes on to argue that the New York free banking law was built on the view of banking by John MacVickar (1787-1868). According to Redlich (1968), MacVickars' view of banking was that

Banks either lend their own credit or they lend their capital. In the former case the businessman is enabled to anticipate his funds by discounting commercial paper which has originated in actual business transactions.... However, when banks discount accommodation paper for investment purposes (that is, bills which have not originated from previous business transactions) the bank then lends its capital to the businessman: it "creates him funds." The former is a legitimate function of banking; the latter "is an irregular operation, the business of the money lender." Thus the decisive point is reached: If the banks should be confined to lending credit they could not go beyond the real needs of commerce. The banks would be safe and the currency secure... . The discounts would rise and fall with the pulse of trade. But when the banks are able to lend out their capital, such harmony does not exist. They lend their capital when they have a surplus note when commerce requires it. 
Despite this full backing with state bonds, there were failures of free banks that entailed losses to note holders.

The second type of regulation enacted to promote bank note safety was the bank liability insurance schemes established by some states (New York, Vermont, Michigan, Indiana, Ohio, and Iowa) during this period. These liability insurance schemes were of two basic types. One type was an insurance fund, sometimes called a safety fund, to which the banks contributed. The other type was a mutual guarantee system, in which banks were responsible for the liabilities of other banks in the system. In neither scheme were bank liabilities guaranteed by the state. ${ }^{29}$ These schemes did prevent note holder losses in the long run. However, because in many cases eventual payouts took place long after a bank's failure, they did not provide 100 percent protection for note holders who needed to redeem their notes shortly after the bank failed.

Governmentally-issued e-moneys will be perfectly safe by definition. Privately-issued emoneys will only be perfectly safe if they are backed by assets or commitments that are themselves perfectly safe. The evidence from state bank notes indicates some type of regulation or government interference will be required for this to occur. This can take one of two forms that were tried with bank notes. Issuers can be required to back their e-moneys 100 percent with perfectly safe, highly liquid assets. The reason for such 100 percent backing schemes, which was in the free banking laws but not in most bank charters, was that there were no such assets available at the time. The required backing for free bank notes was state bonds, which were subject to both price fluctuations and default.

The other possibility is to provide insurance. This was less than perfect in the cases in which it was provided for state bank notes. However, that insurance did not have a government guarantee behind it. The experience with FDIC in the United States shows that today governmentally-provided insurance would make e-moneys perfectly safe.

A lesson about safety can be learned from the experience with state bank notes. It is to avoid marked changes in the regulatory environment without being certain that there will not be adverse consequences on the safety of e-moneys. As shown above, a large fraction of the safety issues with state bank notes occurred after such changes were implemented.

\subsection{No overissuance}

In the period I am considering, the concern about potential overissuance led to restrictions on the minimum denomination of notes that banks could issue. I draw again upon the 1837 and 1838 reports to the New York legislature that I identified in sections 4.3 and 4.4, respectively:

The only legitimate check which intelligent legislation can apply to prevent over issues, consists in an exclusion from circulation of every bill below a given denomination. Any other mode of attempting to regulate by law the amount of money, or its substitute ... is miserable quackery. $(1837,17)$

\footnotetext{
${ }^{29}$ These schemes and the experience with them are discussed in more detail in Weber (2014). The motives were to "prevent panic runs and pay real losses" (this from Golembe and Warburton (1958, p. II-7, f. 2)), much the same as the reasons for the adoption of the FDIC as given by Representative Steagall in 1933.
} 
We know that banks vested with the powers of inflating the currency, and thus altering the standard of value, will, under their present organization, often inflict this dreadful evil on the community....

By rigorously restricting the issuers of paper money from putting into circulation any bills of small denominations, the community might be saved from these terrible visitations; but all history shews that without such restriction, continued repetitions of the visitation may be confidently expected. $(1838,30)$

There were no overissuance problems with bank notes. It is an open question whether this was due to this regulation, to the fact that bank notes were redeemable on demand, or to some other reason.

Such minimum-denomination restrictions seem unlikely to be enacted with e-moneys, since most of those in use today are for small-denomination transactions. There will not be a problem with e-money if the "no credit" restriction is imposed. ${ }^{30}$ The imposition of such a restriction will require supervision to insure that it is not violated. It could also require that firewalls be put in place to isolate e-money issuance from the other activities of the issuer.

In the absence of a "no credit" creation restriction, the requirement that e-money be redeemed in legal money on demand could be put in place to make overissuance less likely. The problem here is the one mentioned in the quotes above. Holders of small-denomination e-moneys are unlikely to present them for redemption very often. Thus, issuers could put a large quantity in circulation without fearing a run.

\subsection{Par exchange}

State bank notes did not generally exchange at par. This lack of par exchange was not caused by any regulations, but rather by the general lack of any mechanism to facilitate its occurrence. Without some type of mechanism in place, exchange rates between different financial instruments are indeterminate. That is, any exchange rate is possible. This indeterminacy holds even for different denominations of any money-like financial instrument. An example will illustrate the point: Suppose the government issues some pieces of paper with two "denominations." Some have a 1 printed on them and some others have a 50 printed on them. However, it will not trade 50 of the piece of paper marked with a 1 for 1 piece of paper with a 50 marked on it. There is no a priori reason to expect that a 50 will trade for $50 \mathrm{1s}$. There are several actions the government could take to make the exchange rate $50: 1$. The most obvious is that it would always exchange the different "denominations" at the given rate whenever any agent wanted to make the exchange. ${ }^{31}$

Taken as a whole, the bank note experience shows that par exchange is unlikely without government intervention. There were only two cases in which a mechanism to enable par exchange of bank notes occurred without government involvement. One was for notes of banks in the same city of geographic area (locally). These banks agreed (implicitly, I think) to exchange notes with each other at par. It also occurred among banks in the Suffolk

\footnotetext{
${ }^{30}$ This assertion assumes that the Quantity Theory holds. Under the "no credit restriction," each dollar of e-money replaces a dollar of legal money, so there is no change in the quantity of money.

${ }^{31}$ Another mechanism used historically is for coins to have different amounts of some commodity (gold or silver).
} 
Banking System. However, there is the question of why such a system came into being only in New England and not in other parts of the country. For example, why did a bank or banks in New York City not set up such a system for that city and the nearby areas in New Jersey and Pennsylvania? The fact that other SBS type systems did not arise suggests that to establish them is difficult.

A possible counter-example to the argument that private par clearing arrangements will not arise is that Visa and MasterCard are accepted at par in the sense that most merchants do not offer a discount for cash. However, the reason why most merchants do not offer discounts for cash (even in countries where it is allowed, such as Canada) is that they would have to give the discount to everyone that paid with cash, even those whose preference was to pay with cash, so that a discount policy could be quite costly for the merchants offering it. $^{32}$

The bank note experience also shows that if a clearing facility were established, then who bears the clearing costs involved - whether it is the holder of or the issuer of the e-money - affects whether e-moneys will exchange at par. ${ }^{33}$ That who bears redemption costs affects whether e-moneys will exchange at par or not can be seen by contrasting the clearing arrangements with state bank notes in general during this period with those under the Suffolk Banking System. To illustrate how clearing worked with a general state bank note during this period, consider the case of the holder of a note from a bank in location A (Bank A) who would take that particular note to a note broker in location B to exchange for notes of a bank in location B. Rather than hold the notes of Bank A, the broker would prefer to have specie, so he would take the note back to Bank A and present it for redemption. However, this would cost the broker postage and insurance, costs which would be passed on to the initial holder in the form of a discount. In other words, the clearing (in this case, redemption) costs were borne by the holder of the Bank A note.

In contrast, under the SBS, the clearing costs were borne by the issuer of the note. Suppose that Bank A in location A took a $\$ 100$ note of Bank B in location B to the Suffolk Bank for clearing. Suffolk would credit Bank A's account with it for $\$ 100$ and debit Bank B's account with it in the same amount. The issuer (Bank B) bore the cost of the clearing because it had to maintain a non-interest-bearing deposit with the Suffolk Bank to be a part of the SBS. ${ }^{34}$

\footnotetext{
${ }^{32}$ Merchants also would generally prefer to impose surcharges on those customers using high-cost (or "premium") credit cards, but are often precluded from doing so by rules imposed by the credit card networks, which prohibit surcharging as a condition for accepting credit cards of a particular brand.

${ }^{33}$ The idea here can be applied to media of exchange in general if the term clearing costs is used in a very general sense. If the medium of exchange is redeemable in lawful money, then clearing costs would mean the costs involved in getting the medium of exchange to a place where such redemption can occur should the holder desire. For the case of multiple media of exchange, clearing costs would have the usual meaning of the term.

${ }^{34}$ The note-clearing arrangements under the National Banking System were somewhat similar to the SBS in that there was a governmentally-run entity that did the crediting of the accounts of national banks. The difference between the national banking arrangement and SBS is that under the national bank note clearing arrangement clearing costs were directly charged to the issuing bank. Banks were charged clearing fees based on the amount of their notes that were presented for clearing. The quantity or value of notes of other banks that they presented had no effect on the amount they were charged.
} 


\section{Summary and conclusion}

The purpose of this paper is to answer the question, Can a privately-issued e-money system, with appropriate regulation and supervision, operate efficiently? The answer from bank note experience is yes, but with appropriate government intervention, regulation, and supervision.

The role for government in minimizing the counterfeiting and hacking of privately-issued e-money is to enact laws against counterfeiting or hacking that carry stiff penalties. In addition, law enforcement agencies would need to be given the resources to apprehend counterfeiters, and the prosecutorial and judicial apparatus would have to commit to imposing stiff penalties on offenders. Further, the government would need to work with the issuers to ensure that the security standards for e-moneys are sufficiently robust to deter counterfeiting or hacking activity. ${ }^{35}$

The role of supervision and regulation to prevent overissuance of privately-issued e-money is either to require no issuance on credit, with the requisite supervision and firewalls, or to require redemption on demand. However, it could also be that a central bank might not have to worry that the creation of e-money would lead to overissuance as long as it can control the very short-term interest rate in the interbank settlement market.

The safety of privately-issued e-moneys can be achieved through either of two types of government intervention. The first is to require issuers to back all issues 100 percent with government currency, short-term government bonds, or deposits at the central bank. The drawback to such regulations is that they would reduce the profitability of issuing e-money and would likely result in issuers imposing transaction fees, in much the same way that today there are fees associated with many deposit accounts and, as previously noted, with M-PESA issued by Safaricom in Kenya. My expectation is that the safety of privately-issued e-money will not be accomplished in this way, because of the inconvenience caused by transaction fees. Further, media of exchange with transaction fees are not really exchanging at par.

The second type of government intervention is government insurance. The argument for it is that even if there is no explicit government insurance, given recent central bank interventions with respect to very liquid financial assets, the public expects that government will step in and bail out the holders of an e-money should the issuer fail and be unable to redeem its issues at par. In other words, I assume that government cannot credibly commit to not intervene should an issuer of e-money fail, especially if it were a "large" or "systemically important" (too-big-to-fail) issuer. If this assumption is correct, then the insurance should be made explicit and implemented in such a way as to minimize the attendant moral hazard problems. ${ }^{36}$

It could turn out that privately-issued e-moneys would exchange at par. A private solution to the par exchange problem along the lines of the Suffolk Banking System might arise.

\footnotetext{
${ }^{35}$ It should be noted that private issuers have a large incentive to combat counterfeiting, because it directly affects their bottom line. Thus, private issuers can be expected to hire highly qualified individuals with the expertise to combat electronic counterfeiting. Bureaucratic restrictions on salaries and bonuses may cause the government to lose out to private enterprises in hiring such talent.

${ }^{36}$ There are many ways in which this could be done. One would be to have the e-money holder bear the first, say, $\$ 100$ of any losses, although this would make the e-money less than perfectly safe.
} 
Consider that Visa and MasterCard transactions occur at par. ${ }^{37}$ However, the fact that a par clearing arrangement with state bank notes only occurred in New England and not in other parts of the country shows that par exchange is unlikely to arise on its own.

My conclusion is that government intervention will be required to achieve par exchange. Again, there are two possible forms that such intervention could take. One is to impose "required par acceptance" similar to that imposed on the banks in the "State Bank of ..." systems, or similar to the par clearing requirement for checks written in the United States. However, a problem with this proposal occurs if an issuer is not a credit-granting financial institution. Such institutions have nothing for which they would have to accept the e-money of another institution as payment. The other government intervention to achieve par exchange is to establish a government entity to clear the e-moneys of various issuers at par.

Of course, all the interventions, regulations, and supervision that seem to be required to make privately-issued e-moneys an efficient medium of exchange have costs associated with them. If these costs are high relative to the benefits, then there is a case for prohibiting privately-issued e-moneys.

The final consideration is whether the central bank (government) should get into the business of issuing e-money. One argument for the central bank to issue its own e-money is that the central bank would save on the costs of providing coins and currency. However, this is not a strong argument in favor of a governmentally-issued e-money. Given the recent innovations in providing coins and currency, the cost savings do not appear to be large.

By far the stronger argument for a governmentally-issued e-money is that it would be a way for the central bank to continue to have a significant source of seigniorage revenue to give it operational independence to conduct monetary policy as it sees fit. The concern is that if privately-issued e-moneys are permitted, they will reduce the demand for currency provided by the central bank. This substitution of privately-issued e-moneys for cental bank currency would reduce the central bank's seigniorage revenue, since the provision of currency is the chief source of central bank seigniorage. Such a reduction of central bank seigniorage is a concern because seigniorage "support[s central bank] operational independence to conduct monetary policy by providing an independent revenue stream outside the government's budget process" (Fung, Molico, and Stuber, 2014, 11). ${ }^{38}$

\footnotetext{
${ }^{37}$ Discounting for cash (or debit cards, for that matter) is allowable in Canada, because the credit card networks adhere to a code of conduct for the credit card and debit card systems. However, discounting for using cash is relatively rare, because it could potentially be quite costly for merchants to implement, since they would have to give it to all customers that used cash.

${ }^{38}$ The period under consideration here is relevant because states did not have the power to create money. It was explicitly prohibited by the Constitution. The power to create money was in the hands of banks because they could issue notes (and deposits). However, states found a way to tax money creation - they taxed banks. According to Sylla, Legler, and Wallis (1987, 400), many states "did rely for extensive periods on significant amounts of bank revenue - a third or more of all ordinary state revenues."

This experience shows that it is possible to obtain "seigniorage" from money creation even if the government or a central bank is not the money issuer. My expectation, however, is that central banks would not be allowed to directly levy any kind of fee on e-money issuers, because national governments would be unlikely to give up that prerogative. If such a fee or other charge on e-money issuers were to be levied, the national government would be the one levying it, and the central bank would have to go to the national government to get a piece of the revenue. An example is the case of Kenya, where the national government has introduced a $10 \%$ excise duty tax on transaction fees for all money transfer services provided by cellular
} 
To evaluate how strong this argument is requires future research to provide answers to the following questions:

- How much will the demand for coin and currency fall if there are only privately-issued e-moneys and no governmentally-issued e-money?

- How large will the demand for a governmentally-issued e-money be if there are privatelyissued e-moneys?

- How large will the demand for a governmentally-issued e-money be if it is the only e-money?

- How costly will it be to set up the necessary infrastructure for a governmentally-issued e-money?

- What will the clearing connections be between the governmentally-issued e-money and privately-issued e-moneys?

phone providers, banks, money transfer agencies and other financial service providers, which directly affects Safaricom and its M-PESA service. 


\section{References}

Ales, L., F. Carapella, P. Maziero, and W. E. Weber (2008): "A Model of Bank note Discounts," Journal of Economic Theory, pp. 5-27.

Connolly, P. M., And R. W. Eisenmenger (2000): "The Role of the Federal Reserve in the Payments System," in The Evolution of Monetary Policy and the Federal Reserve System Over the Past Thirty Years: A Conference in Honor of Frank E. Morris, ed. by R. W. Kopcke, and L. E. Browne, pp. 131-161. Federal Reserve Bank of Boston, Boston.

Dillistin, W. (1949): Bank Note Reporters and Counterfeit Detectors. The American Numismatic Society, New York and London.

Fung, B., M. Molico, And G. Stuber (2014): "Electronic Money and Payments: Recent Developments and Issues," Bank of Canada Discussion Paper.

Golembe, C. H., and C. Warburton (1958): "Insurance of Bank Obligations in Six States During the Period 1829-1866," Federal Deposit Insurance Corporation.

Haxby, J. A. (1988): Standard Catalog of United States Obsolete Bank Notes, 1782-1866. Krause Publications, Iola, WI.

Hildreth, R. (1840): Banks, Banking, and Paper Currencies. Whipple \& Damrell, Boston, MA.

Minm, S. (2007): A Nation of Counterfeiters, Capitalists and Con Men, the Making of the United States. Harvard University Press, Cambridge, MA.

Mishkin, F. S. (2009): The Economics of Money, Banking, and Financial Markets, 9th edition. Addison-Wesley, New York.

Mundell, R. (1998): "The Case for the Euro - I," Wall Street Journal (24 March).

Nigh, B. (2013): "Follow the Money: The Origins of the Secret Service," The National Archives, 17 January.

ReduICH, F. (1968): The Molding of American Banking: Men and Ideas. Johnson Reprint Corporation, New York and London.

Rolnick, A. J. (1999): "Maintaining a Uniform (Electronic) Currency," Journal of Money, Credit and Banking, pp. 674-676.

Rolnick, A. J., And W. E. Weber (1983): "New Evidence on the Free Banking Era," American Economic Review, 73(5), 1080-1091.

(1988): "Explaining the Demand for Free Bank Notes," Journal of Monetary Economics, 21, 47-71.

Root, L. C. (1901): "Twenty Years of Bank Currency Based on General Commercial Assets," Sound Currency, 8, 209-232. 
Rutner, J. L. (1974): "Money in the Antebellum Economy: Its Composition, Relation to Income and Its Determinants," Ph.D. dissertation, The University of Chicago.

Sylla, R., J. B. Legler, and J. J. Wallis (1987): "Banks and State Public Finance in the New Republic: The United States, 1790-1860," Journal of Economic History, 47(2), 391-403.

WeBer, W. E. (2014): "Bank Liability Insurance Schemes in the United States Before 1865," unpublished manuscript. 


\section{Appendix}

The Bank of Pennsylvania was a large and important bank in the United States during the first half of the nineteenth century. If it were in existence today, it might be deemed as being "systemically important" or "too big to fail." But, in fact, it did fail. The failure followed the bank's suspension of payment on its notes and deposits on 25 September 1857. This appendix discusses the public reaction to this failure, with particular emphasis on the extent to which there were calls for any type of bailout of the bank. It finds that there was only minor public reaction to the failure.

The appendix proceeds as follows. Section A.1 reports evidence of the importance of the bank to the financial system. Section A.2 describes the events immediately following its failure. Section A.3 describes the public reaction to the general suspension of payments that followed the Bank of Pennsylvania's suspension of payments. Section A.4 examines whether there was any discussion about bailing out the bank. Section A.5 provides some additional material.

\section{A.1 The financial importance of the Bank of Pennsylvania}

The Bank of Pennsylvania began business on 3 June 1793. It was the second bank to go into operation in Philadelphia (the Bank of North America was the first both in Philadelphia and in the country as a whole), and the thirteenth to go into operation in the country.

The financial importance of the Bank of Pennsylvania can be seen from the following facts:

- Until 1856, it had the largest capital of any bank in Philadelphia, with the exception of a couple of years in the 1830s.

- The circulation of its notes was among the largest of all Philadelphia banks during most of its existence. For example, in November 1855 and in November 1856 it had the largest note circulation of any Philadelphia bank, and approximately one-sixth of all notes issued by Philadelphia banks were Bank of Pennsylvania notes. And even after its failure in November 1857, its circulation was the largest of any Philadelphia bank and amounted to 20 percent of all Philadelphia bank notes outstanding.

- It was a large respondent bank. For example, in November 1855 it had the second largest amount due to other banks, amounting to 14 percent of the "Due to other banks" on the books of Philadelphia banks. In November 1856, it was still the second largest, and had 19 percent of the total. And in November 1857, after its failure, the amount it owed other banks was the largest of any Philadelphia bank and amounted to almost a quarter of "Due to other banks."

- In a 25 November 1857 report of the commissioners appointed to investigate the condition of the Bank of Pennsylvania, the amount of circulation was $\$ 527,787$, and the amount due to banks was $\$ 1,107,118.35$, of which $\$ 964,326.58$ was owed to Philadelphia banks.

Further evidence of the importance of the Bank of Pennsylvania is as follows: according to an article in the Philadelphia Press on 4 November 1857, "It had been the financial agent 
of the Commonwealth in many of its moneyed transactions." The article went on to say that "generation after generation had grown up in the belief that it was one of the safest and best banks in the Union."

\section{A.2 Events immediately following the failure}

The events that occurred on 25 September 1857, the day the Bank of Pennsylvania suspended payments, are well reported by the Philadelphia Inquirer the next day:

Yesterday was a day of extraordinary excitement in this city. Soon after the opening of the doors of the Bank of Pennsylvania, it was deemed expedient to close them. Immediately the intelligence spread with the greatest possible celerity, and crowds soon assembled in Second and Third streets, and indeed in the neighborhood of all our leading monetary institutions. All sorts of speculations were indulged, and many extravagant reports were circulated. The effect was to produce a run upon the banks generally for specie. All of them, except the Bank of Pennsylvania, paid out, either in whole or in part, until three o'clock, the usual hour of closing.

The other Philadelphia banks suspended payments beginning the morning of 26 September 1857. This suspension and the events that followed are described in an article in the Philadelphia Press on 4 November 1857: after the suspension of payments by the Bank of Pennsylvania, "a general run upon all the banks of the city commenced, which resulted in suspending and which eventually led to the suspension of nearly all of the banks in the United States." The part of this statement about the general suspension of Philadelphia banks is correct. The part about the suspension being general throughout the country is not. For example, banks in New York and New England did not suspend.

\section{A.3 The immediate reaction to the general suspension of payments}

The immediate reaction to the general suspension of payments by Philadelphia banks appears to have been relatively mild. This immediate mild reaction was seemingly the result of two factors. The first was the expectation that note holders and depositors would not suffer large losses. The second was the expectation that the banking system and the payments system would continue to function close to normally. That these two factors were the reasons for the mild reaction is apparent in this article in the Philadelphia Inquirer on 26 September 1857:

Their [the presidents of the banks of Philadelphia] decision [to suspend payments], we venture to affirm, will be cordially approved by the community. No loss is likely to occur to note holders and depositors in any case, while even the stockholders will only require the exercise of a little patience till the excitement subsides, and confidence is fully restored. Far better for the Banks to have agreed upon suspension in the manner described, and with a liberal supply of specie still in their vaults, than to have been compelled to such a course, after they had lost all their coin... The inconvenience that will be experienced, will be as nothing, 
compared with embarrassments and losses that would ensue from a different policy. It is quite probable that there will be a slight depreciation in the notes of the Banks, as compared with specie, but they will doubtless pass with the utmost readiness, and will of course be received by the various institutions, in liquidation of all claims against them... There may be some little excitement today, in consequence of a movement of such importance, but we feel satisfied that there will be no alarm, but on the contrary, the community at large will sustain the course that has been recommended by the Bank Presidents. Nay, as far as we have been able to ascertain, it is in response to public opinion, and will at once contribute to relieve the deep anxiety and the severe pressure that has so long been experienced.

More insurance that the banking and payment systems would not be disrupted occurred on 13 October 1857, when the legislature of Pennsylvania passed "An Act Providing for the Resumption of Specie Payments by the Banks, and for the Relief of Debtors." This Act suspended the penalties usually associated with the suspension of payment by banks and specifically allowed banks to continue to make loans, discount bills, and issue notes during the period in which they suspended payments. This Act also contained the following provision, which I think was intended to keep the payments system functioning, at least locally:

That the said banks are hereby required ... to receive at par, in payment of all debts due or to become due to them respectively, the notes of all the solvent banks of the commonwealth which paid specie for all their liabilities on and immediately prior to the first day of September last, and which shall continue solvent, and the said banks are also hereby authorized to pay out, in all their business transactions and discounts, the said notes, so long as the banks issuing the same shall remain solvent....

Particularly notable is that the Act permitted banks to pay out the notes of other banks. Such a practice was usually prohibited.

\section{A.4 Was there any discussion of whether to bail out the Bank?}

In November 1857, the notes of the Bank of Pennsylvania were quoted at a 30 percent discount against the notes of other Philadelphia banks. Yet, there was no discussion in newspapers of bailing out note holders or depositors after the failure of the Bank of Pennsylvania. There are several possible, not mutually exclusive, reasons for this lack of a discussion of bailouts:

1. It was not considered to be something that governments would do. I have no information as to whether this was the case at the time.

2. Note holders were generally wealthy and could bear the losses. Most notes were of $\$ 5$ denomination or larger, the equivalent of $\$ 100$ or larger bills today. 
3. Note holders could and did use them to pay off debts to the bank, so that the amount on which losses occurred was small. There is some evidence that this in fact occurred. In the 25 November 1857 report of the commissioners appointed to investigate the condition of the Bank of Pennsylvania, the circulation of the bank was $\$ 527,787$. In a subsequent report by the commissioners on 2 January 1858 (the document is dated 2 January 1857 , but that has to be a mistake), the circulation was only $\$ 44,275$. Given that payments at the Bank of Pennsylvania were suspended during this period, it seems likely that the large decrease in circulation occurred as a result of many of the bank's debtors paying off their loans dollar-for-dollar with Bank of Pennsylvania notes.

It is possible that one other set of creditors suffered losses; namely, other banks. They were third in line to be paid off after note holders (first) and depositors (second). In January 1858 , the amount due to banks was still $\$ 357,988.83$. However, it is unlikely that banks would have been objects of much sympathy by the taxpaying public.

The evidence suggests that the stockholders of the bank lost all of their investments. Interestingly, there was some interest in bailing out some of these shareholders. On 10 November 1857, the Philadelphia Press advocated:

In many instances the losses [suffered by shareholders] will fall upon individuals who can illy bear them, and whose whole means are locked up in the bank. If anything can be done for their relief consistent with the safety of the public at large, we shall greatly rejoice. [italics in the original]

And in another article in the same issue was the same idea:

It will be the sacred duty [of the bank's new board of directors] to cause all such parties [the president and his "aides and abettors in fraud and wrong"], if they can be found, to disgorge their ill-gotten funds, for the sake of the widows, the orphans, the trusts, and the charities, whose moneys have been invested in the stock of this bank.

\section{A.5 Skin in the game matters for bank directors (or bank regula- tors)}

The importance of incentives for bank directors was recognized at the time. In discussing the failure of the bank, the Philadelphia Press on 10 November 1857, again, had this opinion:

A number of the directors had so little pecuniary interest in the affairs of the bank that they could not in any event lose much by its operations, and they, therefore, had no great motive for scrutinizing its accounts so closely, and for exacting fidelity from its officers, as rigidly, as they should have done. 